\title{
Isolation, Characterization and X-ray Structure Determination of the Schiff Base Ligand: 5-Methyl-2-phenyl-4-[phenyl-(4-phenyl-thiazol-2-ylamino)- methylene]-2,4-dihydro-pyrazol-3-one
}

\author{
Amit S. Thakar ${ }^{a}$, Holger B. Friedrich ${ }^{a}, K_{\text {Krishnalal T. Joshi }}{ }^{b}$ and Glenn E.M. Maguire, \\ ${ }^{a}$ School of Chemistry and Physics, University of KwaZulu-Natal, Westville Campus, Private Bag X54001, Durban, 4000, South Africa. \\ ${ }^{b}$ Department of Chemistry, Navjivan Science College, Dahod, Gujarat, 389 151, India.
}

Received 12 June 2014, revised 20 December 2014, accepted 23 December 2014.

\begin{abstract}
The structure of the amine tautomer of the new Schiff base derived from 4-benzoyl-5-methyl-2-phenyl-2,4-dihydro-pyrazol3-one (2) and 4-phenyl-thiazol-2-ylamine (3) was confirmed by means of single crystal X-ray diffraction. The title compound (4) was synthesized and crystals were grown from a mixture of dichloromethane and $\mathbf{n}$-hexane (1:3). Single crystal $\mathrm{X}$-ray diffraction analysis show that the structure is primarily stabilized by strong intramolecular N3-H3A $\cdots \mathrm{O} 1$ hydrogen bonds [N3-H3A = $0.883(19) \AA, \mathrm{H} 3 \mathrm{~A} \cdots \mathrm{O} 1=1.925(18) \AA, \mathrm{N} 3 \cdots \mathrm{O} 1=2.6901(13) \AA$, with an angle for $\left.\mathrm{N} 3-\mathrm{H} 3 \mathrm{~A} \cdots \mathrm{O} 1=144.1(17)^{\circ}\right]$ and this leads to the formation of a pseudo nine-membered hydrogen bonded pattern. Elemental analysis, FTIR and NMR analyses have been employed to characterize the crystal.
\end{abstract}

KEYWORDS

Pyrazolone, thiazole, Schiff base, tautomer, X-ray structure.

\section{Introduction}

The chemistry of pyrazolone derivatives has attracted much attention because of their interesting structural properties and applications in diverse areas. ${ }^{1}$ They can be used in laser materials, as ${ }^{1} \mathrm{H}$ NMR shift reagents, in chromatographic studies and in the petrochemical industry. ${ }^{2}$ Furthermore, they are useful reagents for the extraction and separation of various metal ions. ${ }^{3}$ Moreover, particular interest exists due to the ability of these compounds to exhibit several tautomeric forms: keto-imine, imine-ol and keto-amine. ${ }^{4}$ These Schiff base ligands have been studied extensively due to their ease of synthesis and their ability to be readily varied both sterically and electronically. On the other hand, the aminothiazole ring system is a useful structural element in medicinal chemistry. ${ }^{5}$ We have reported substituted pyrazolones with various amino thiazoles and their molecular structures were determined. ${ }^{6}$ The ligands can exist in three tautomeric forms but the keto-amine form is predominant in the solid state. In Schiff base compounds, the imine nitrogen can act as an interor intramolecular hydrogen bond acceptor. We are interested in exploring the essence of inter- and intra-molecular interactions of the ligand in metal stabilization, extraction and florescence effects in green chemistry.

As a part of our ongoing studies into the structure and utility of Schiff base ligands synthesized from pyrazolone and thiazole, we report the synthesis (Scheme 1), spectral properties, crystal structure, tautomerism (Scheme 2), and weak interactions of the Schiff base prepared from the condensation of 4-benzoyl-5methyl-2-phenyl-2,4-dihydro-pyrazol-3-one (2) and 4-phenylthiazol-2-ylamine (3).

\section{Experimental}

2.1. Materials and Measurements

The compound 5-methyl-2-phenyl-2,4-dihydro-pyrazol-

* To whom correspondence should be addressed. E-mail: maguireg@ukzn.ac.za 3-one (1) was obtained from Prima Chemicals, Ahmedabad, India. Methanol and dioxane were obtained from SD's Fine Chemical Ltd., India. Absolute alcohol was obtained from Baroda Chem. Industry Ltd. and was used after distillation. Calcium hydroxide and benzoyl chloride were obtained from Samir Tech. Chem. Pvt. Ltd. All the chemicals used were of AR grade. Solvents used in this study were purified following standard procedures. For the synthesis of compound 2, the benzoylation step was carried out in the presence of calcium hydroxide as per a literature method. ${ }^{8}$

The elemental analysis was obtained by using a Flash Elemental Analyzer-1112. Infrared spectra (IR) were measured with a PerkinElmer Precisely 100 FTIR spectrometer. ${ }^{1} \mathrm{H}$ and ${ }^{13} \mathrm{C}$ NMR spectra were measured at 400.22 and $100.63 \mathrm{MHz}$, respectively, with a Bruker Avance III $400 \mathrm{MHz}$ spectrophotometer by using TMS (tetramethylsilane) as the internal reference. Melting points were recorded on an Ernst Leitz Wetzlar hot stage melting point apparatus. Reactions were monitored by thin layer chromatography (TLC) on aluminum-backed plates coated with Merck Kieselgel 60 F254 silica gel. TLC plates were visualized by $\mathrm{UV}$ radiation at a wavelength of $254 \mathrm{~nm}$. Crystals suitable for X-ray diffraction were obtained by slow evaporation of the title compound in a combination of dichloromethane with n-hexane (1:3) at room temperature. The data collection and cell refinement were achieved by using Bruker APEX2 and SAINT-Plus respectively. ${ }^{9}$ The data reduction was performed with SAINT-Plus and XPREP. ${ }^{9}$ The program used to solve and refine the structure was SHELXS 97..10 For molecular graphics ORTEP-3 $3^{11}$ and OLEX $2^{12}$ were employed to prepare the material for publication. $^{12}$

2.2. Synthesis of Schiff Base Ligand

5-Methyl-2-phenyl-2,4-dihydro-pyrazol-3-one (1) (2 g, $11.5 \mathrm{mmol})$ was dissolved in hot dioxane $(20 \mathrm{~mL})$ in a flask

ISSN ISSN 0379-4350 Online / (02015 South African Chemical Institute / http://saci.co.za/journal

DOI: http://dx.doi.org/10.17159/0379-4350/2015/v68a6 


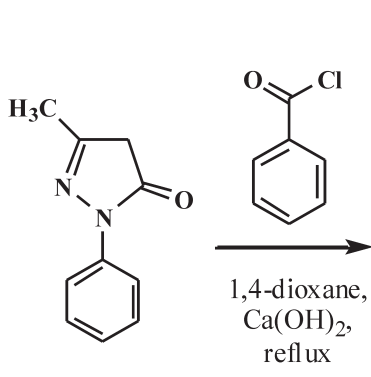

1<smiles>CC1=NN(c2ccccc2)C(=O)C1C(=O)c1ccccc1</smiles>

2

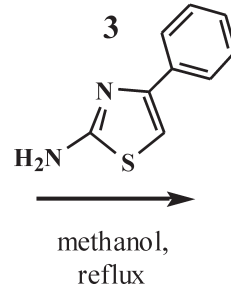

Scheme 1

Synthetic pathway for the Schiff base ligand.<smiles>Cc1nn(-c2ccccc2)c(O)c1/C(=N/c1nc(-c2ccccc2)cs1)c1ccccc1</smiles>

(I)<smiles>CC1=NN(c2ccccc2)C(=O)C1=C(Nc1nc(-c2ccccc2)cs1)c1ccccc1</smiles>

4
(II)

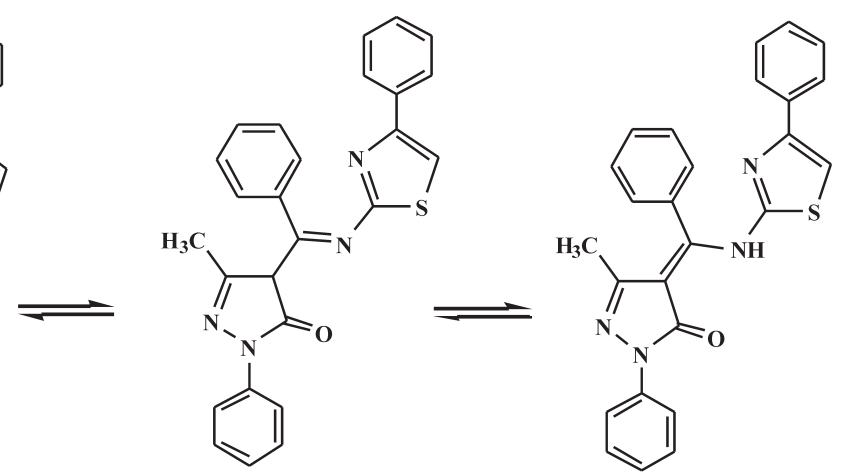

(III)

Imine-ol tautomer

Keto-imine tautomer

Scheme 2

The possible tautomeric forms of the Schiff base.

equipped with a stirrer, separating funnel and reflux condenser. Calcium hydroxide $(1.7 \mathrm{~g}, 23 \mathrm{mmol})$ was added to this solution, followed by benzoyl chloride $(3.23 \mathrm{~g}, 11.5 \mathrm{mmol})$ added dropwise with precaution, as this reaction was exothermic. During this addition the reaction mass was converted into a thick paste. After the complete addition, the reaction mixture was refluxed for half an hour and then it was poured into dilute hydrochloric acid $(50 \mathrm{~mL}, 2 \mathrm{M})$. The crude product 4-benzoyl5-methyl-2-phenyl-2,4-dihydro-pyrazol-3-one (2) obtained was separated by filtration and recrystallized from n-hexane to give a bright yellow crystalline solid $(2.5 \mathrm{~g}, 80 \%)$.

A solution of $2(1 \mathrm{~g}, 3.6 \mathrm{mmol})$ in methanol $(30 \mathrm{~mL})$ was added to another solution of 4-phenyl-thiazol-2-ylamine (3) $(0.63 \mathrm{~g}$, $3.6 \mathrm{mmol})$ in methanol $(20 \mathrm{~mL})$ under an inert atmosphere. The reaction mixture was refluxed for three hours. Completion of the reaction was monitored by TLC using hexane/ethyl acetate (8:2). The reaction was allowed to cool to room temperature and stirred overnight. A yellow precipitate formed which was then filtered and washed with methanol $(10 \mathrm{~mL})$. The crude product was purified by crystallization from ethanol to give brown crystals of the desired product 5-methyl-2-phenyl-4-[phenyl-(4-phenylthiazol-2-ylamino)-methylene]-2,4-dihydro-pyrazol-3-one (4)
$(1.2 \mathrm{~g}, 77 \%), \mathrm{mp} .=199{ }^{\circ} \mathrm{C} . \mathrm{IR}\left(\mathrm{cm}^{-1}\right): 3153,1616,1591,1540,1516$, $1490,1385,1353,1209,1196,839,821,724,688 ; \delta_{\mathrm{H}}(400 \mathrm{MHz}$, $\left.\mathrm{CDCl}_{3}\right): 13.73(0.5 \mathrm{H}, \mathrm{s}, \mathrm{NH}), 7.97(2 \mathrm{H}, \mathrm{d}, J=7.84 \mathrm{~Hz}, \mathrm{ArH}), 7.71$ $(2 \mathrm{H}, \mathrm{d}, J=7.28 \mathrm{~Hz}, \mathrm{ArH}), 7.57(3 \mathrm{H}, \mathrm{m}, \mathrm{ArH}), 7.44(2 \mathrm{H}, \mathrm{d}, J=7.24$ $\mathrm{Hz}, \operatorname{ArH}), 7.36(2 \mathrm{H}, \mathrm{t}, J=7.92 \mathrm{~Hz}, \operatorname{ArH}), 7.32(2 \mathrm{H}, \mathrm{t}, J=7.42 \mathrm{~Hz}$, $\mathrm{ArH}), 7.25(2 \mathrm{H}, \mathrm{d}, J=7.16 \mathrm{~Hz}, \mathrm{ArH}), 7.12(\mathrm{t}, J=6.36 \mathrm{~Hz}, \mathrm{ArH}), 6.84$ $(1 \mathrm{H}, \mathrm{s}, \mathrm{CH}), 4.71(0.5 \mathrm{H}, \mathrm{s}, \mathrm{OH}), 1.48\left(3 \mathrm{H}, \mathrm{s}, \mathrm{CH}_{3}\right) \mathrm{ppm} ; \delta_{\mathrm{C}}$ $\left(100 \mathrm{MHz}, \mathrm{CDCl}_{3}\right): 165.04,160.88,159.27,153.04,147.55,138.42$, $136.09,134.47,131.15,129.47,129.34,126.04,119.39,107.58$, $103.39,15.97$ ppm.

\section{Results and Discussion}

\subsection{Characterization of the Ligand}

The compound was stable at room temperature, non-hygroscopic, insoluble in n-hexane, petroleum ether and toluene, and soluble in chloroform, dichloromethane and ethyl acetate. Analytical data are shown in Table 1.

The general structure of these ligands is such that they can exist in three tautomeric forms as shown in Scheme 2. Detailed solution and solid-state studies of the ligand were carried out to establish the predominant tautomer.

Table 1 Analytical data of the Schiff base and precursor.

\begin{tabular}{|c|c|c|c|c|c|c|c|c|}
\hline \multirow[t]{2}{*}{ Compound } & \multirow[t]{2}{*}{ M.F. } & \multirow[t]{2}{*}{ M.Wt. } & \multirow[t]{2}{*}{ Yield/\% } & \multirow[t]{2}{*}{ M.p. $/{ }^{\circ} \mathrm{C}$} & \multicolumn{4}{|c|}{ Elemental analysis/\% (found/calcd.) } \\
\hline & & & & & C & $\mathrm{H}$ & $\mathrm{N}$ & S \\
\hline 2 & $\mathrm{C}_{17} \mathrm{H}_{14} \mathrm{~N}_{2} \mathrm{O}_{2}$ & 278.31 & 80 & 85 & $73.28(73.37)$ & $5.12(5.07)$ & $10.13(10.07)$ & - \\
\hline 4 & $\mathrm{C}_{26} \mathrm{H}_{20} \mathrm{~N}_{4} \mathrm{OS}$ & 436.53 & 77 & 199 & $77.67(77.54)$ & $4.59(4.62)$ & $12.80(12.83)$ & $7.31(7.35)$ \\
\hline
\end{tabular}




\subsection{IR and NMR Spectroscopy}

The IR spectra of this family of ligands exhibit two characteristic bands at 3135 and $1616 \mathrm{~cm}^{-1}$, which can either be assigned to $v \mathrm{O}$ $\mathrm{H}$ and $v \mathrm{C}=\mathrm{N}$, respectively, for the tautomeric imine-ol form (Scheme 2, I) or $v \mathrm{~N}-\mathrm{H}$ and $v \mathrm{C}=\mathrm{O}$ respectively for the keto-amine form (Scheme 2, III) of the ligand. We assigned these two peaks to $v \mathrm{~N}-\mathrm{H}$ and $v \mathrm{C}=\mathrm{O}$, respectively, for the latter form in conjunction with the information obtained from crystallographic studies (discussed below).

The ${ }^{1} \mathrm{H}$ and ${ }^{13} \mathrm{C}$ NMR spectra of the ligand were recorded in $\mathrm{CDCl}_{3}$ at room temperature and the data are presented in the experimental section. The signals due to methyl protons appear as singlets at $\delta 1.48 \mathrm{ppm}$. Another singlet was observed at $\delta 6.84$, which corresponds to the only proton of the thiazole ring. In the aromatic region between $\delta 7.13$ and 7.98 ppm overlapping doublets and multiplets are observed. One broad singlet, corresponding to a single proton, is observed at $\delta 13.73 \mathrm{ppm}$. This signal disappeared when a $\mathrm{D}_{2} \mathrm{O}$ exchange experiment was carried out and integrates exactly for one proton, which suggests that only one tautomeric form of the ligand exists in solution under the experimental conditions. Although no temperature dependent experiments were carried out, comparing with the solid state study, this signal was assigned to $\mathrm{NH}$. However, assignment of this peak to $\mathrm{OH}$ cannot be ruled out, provided the solid state structural evidence is not considered. This assignment is not without contention as several researchers have reported the determination of the imine-ol (I) tautomer in solution. For example, in the case where an $\mathrm{N}$-oxime derivative was made, the imine-ol molecule is present exclusively. A mixture of the two tautomers has also been reported in solution. ${ }^{13}$ However it is important to note that in the vast majority of examples where X-ray data are shown, the crystal structure is invariably the keto-amine isomer (III) ${ }^{7,14}$

In the ${ }^{13} \mathrm{C}$ NMR spectrum the carbon atom of the methyl group appears at $\delta 15.97 \mathrm{ppm}$. The singlet appearing at $\delta 103.39 \mathrm{ppm}$ is assigned to the carbon atom of the C-N moiety; the significant upfield shift is due to the electron donating phenyl group attached to it. The signal appearing at $\delta 107.58 \mathrm{ppm}$ can be assigned to the $\mathrm{C}-\mathrm{H}$ of the thiazole ring. The correlation between carbon and hydrogen can be seen from the HSQC data (see online supplement). The carbon atoms of the three benzene rings exhibit signals in the range of $\delta 119-139 \mathrm{ppm}$. In the low field region, five signals were observed at $\delta 147.55,153.04,159.27,160.88$ and $165.04 \mathrm{ppm}$, which are associated with the carbon atoms of the heterocyclic ring. The most deshielded signal at $\delta 165.04 \mathrm{ppm}$ can be assigned to the $\mathrm{C}=\mathrm{O}$ carbon and the next signal at $\delta 160.88 \mathrm{ppm}$ was assigned to the carbon of $\mathrm{C}=\mathrm{N}$.

\subsection{X-ray Crystallography Studies}

Crystal data collection parameters are given in Table 2.

The molecular structure of the ligand (Fig. 1) was determined from single crystal X-ray studies.

This structure determination gives evidence for the existence of the keto-amine form (in the solid state). An analysis of the structural data shows that the C10-O1 distance in the pyrazolone moiety is $1.244(15) \AA$, which is significantly shorter than the distances found for $\mathrm{COH}$ in some pyrazolone derivatives, $1.341,1.346 \AA^{15}$ and $1.331 \AA_{;}{ }^{16}$ however, they are close to the distances found for $\mathrm{C}=\mathrm{O}$ in similar compounds, $1.262 \AA .{ }^{15}$ The C10-N1 distance of the imine moiety is at 1.376(15) $\AA$, which is significantly longer than those found for $\mathrm{C}=\mathrm{N}$ in pyrazolone compounds, $1.298(2) \AA^{17}$ and 1.383(2) $\AA^{1,}$, but similar to that found for C-N (1.339(3) $\AA) .{ }^{18}$ It should also be noted that the proton associated with N3 can be located from the Fourier
Table 2 Crystal data and structure refinement of the new Schiff base.

\begin{tabular}{ll}
\hline Empirical formula & $\mathrm{C}_{26} \mathrm{H}_{20} \mathrm{~N}_{4} \mathrm{OS}$ \\
Formula weight & 436.52 \\
Temperature & $173(2) \mathrm{K}$ \\
Wavelength & $0.71073 \AA$ \\
Crystal system & Monoclinic \\
Space group & $\mathrm{P}_{21 / \mathrm{c}}$ \\
Unit cell dimensions & $\mathrm{a}=13.9867(3) \AA$ \\
& $\mathrm{b}=21.2378(4) \AA, \beta=95.7990(10)$ \\
& $\mathrm{C}=7.22470(10) \AA$ \\
Volume & $2135.09(7) \AA^{3}$ \\
Z & 4 \\
Density (calculated) & $1.358 \mathrm{Mg} / \mathrm{m}^{3}$ \\
Absorption coefficient & $0.179 \mathrm{~mm}{ }^{-1}$ \\
F(000) & 912 \\
Crystal size & $0.46 \times 0.25 \times 0.23 \mathrm{~mm}^{3}$ \\
Theta range for data collection & $1.75-28.41$ \\
Reflections collected & 58780 \\
Independent reflections & $5358[\mathrm{R}($ int $)=0.0260]$ \\
Completeness to theta $=28.41^{\circ}$ & $99.9 \%$ \\
Absorption correction & $\mathrm{Semi}-\mathrm{empirical} \mathrm{from} \mathrm{equivalents}$ \\
Max. and min. transmission & 0.9600 and 0.9223 \\
Refinement method & Full-matrix least-squares on $\mathrm{F}^{2}$ \\
Data / restraints / parameters & $5358 / 0 / 294$ \\
Goodness-of-fit on F $\mathrm{F}^{2}$ & 1.035 \\
Final R indices [I 2 sigma(I)] & $\mathrm{R} 1=0.0373, \mathrm{wR} 2=0.0913$ \\
R indices (all data) & $\mathrm{R} 1=0.0476, \mathrm{wR} 2=0.0978$ \\
Largest diff. peak and hole & $0.572 \mathrm{~d}-0.285 \mathrm{e} . \AA^{-3}$ \\
\hline
\end{tabular}

difference map. The bond between the C9 and C11 carbon atoms is a double bond and it further concludes that the resulting Schiff base is present as a keto-amine (III in Scheme 2) tautomeric form, rather than the imine-ol (I in Scheme 2) in the solid state. However, the $\mathrm{N}-\mathrm{H}$ proton is clearly hydrogen bonded

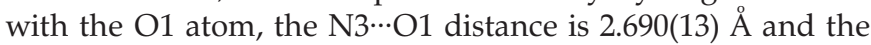
N3-H3A …O 1 angle is $144.1(17)^{\circ}$ (Table 3 ). The possibility of the attachment of H3A with C9 (imine-one form-II) is ruled out on the basis of the angles around C9. The summation of the three angles C7-C9-C10, C7-C9-C11 and C10-C9-C11 is 359.91 and is close to the ideal value of 360 expected from the coplanar C7, C9, C10 and C11 atoms. Selected bond angles and bond lengths are summarized in Table 4.

Thus, the crystal structure study conclusively proves the existence of this compound in the keto-amine (III) form.

With the help of XRD analysis, the possible weak interactions of the resulting Schiff base were also studied (Fig. 2). The molecular structure is primarily stabilized by a strong intra molecular N3-H3A ‥ 1 hydrogen bond [N3-H3A = 0.883(19) $\AA, \mathrm{H} 3 \mathrm{~A} \cdots \mathrm{O} 1$ $=1.925(18) \AA, \mathrm{N} 3 \cdots \mathrm{O} 1=2.6901(13) \AA$, and the angle $\mathrm{N} 3-\mathrm{H} 3 \mathrm{~A} \cdots \mathrm{O} 1=144.1(17)^{\circ}$ ] and this leads to the formation of a

Table 3 Intramolecular hydrogen-bond distances $(\AA)$ and angles $\left(^{\circ}\right)$ for the ligand in the crystal lattice.

\begin{tabular}{lcccc}
\hline $\mathrm{D} \mathrm{H} \cdots \mathrm{A}$ & $\mathrm{D}-\mathrm{H} / \AA$ & $\mathrm{H} \cdots \mathrm{A} / \AA$ & $\mathrm{D} \cdots \mathrm{A} / \AA$ & $\mathrm{D}-\mathrm{H} \cdots \mathrm{A} /$ \\
\hline $\mathrm{N} 3-\mathrm{H} 3 \mathrm{~A} \cdots \mathrm{O} 1$ & 0.88 & 1.93 & $2.6901(13)$ & 144.1 \\
$\mathrm{C} 6-\mathrm{H} 6 \cdots \mathrm{O} 1$ & 0.95 & 2.34 & $2.9626(15)$ & 122 \\
$\mathrm{C} 2-\mathrm{H} 2 \cdots \mathrm{N} 2$ & 0.95 & 2.43 & $2.7706(16)$ & 101 \\
$\mathrm{C} 26-\mathrm{H} 26 \cdots \mathrm{N} 4$ & 0.95 & 2.54 & $2.8728(16)$ & 100 \\
$\mathrm{C} 17-\mathrm{H} 17 \cdots \mathrm{O} 1{ }^{\mathrm{a}}$ & 0.95 & 2.42 & $3.2954(16)$ & 153 \\
$\mathrm{C} 23-\mathrm{H} 23 \cdots \mathrm{N}{ }^{\mathrm{b}}$ & 0.95 & 2.61 & $3.5437(16)$ & 166 \\
\hline
\end{tabular}

${ }^{a} x, 3 / 2-y, 1 / 2+z,{ }^{b}-1+x, 3 / 2-y, 1 / 2+z$. 


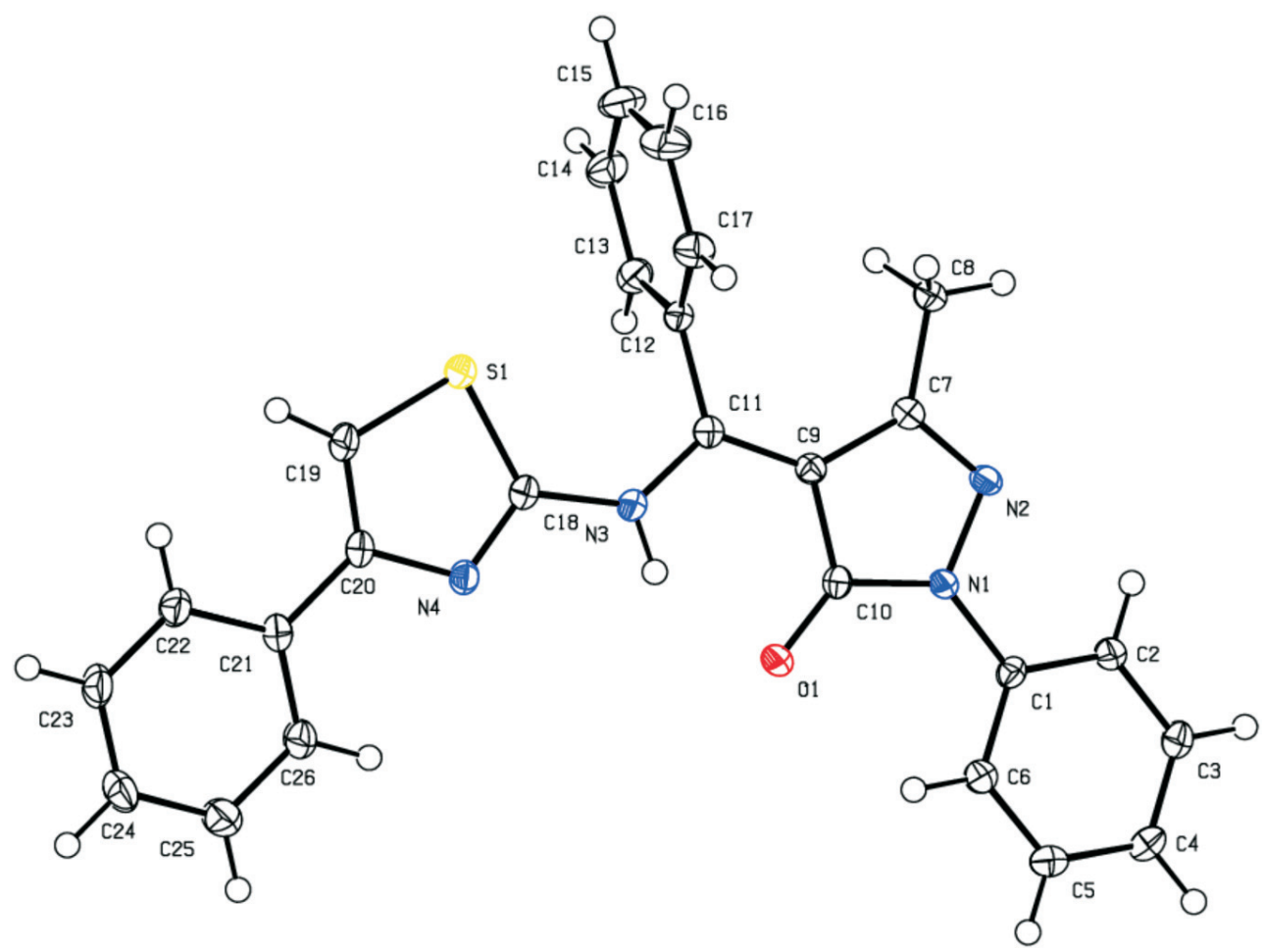

Figure 1 ORTEP diagram of the ligand showing the atom numbering scheme (50\% probability factor for the thermal ellipsoids).

Table 4 Summary of selected bond lengths $(\AA)$ and bond angles $\left({ }^{\circ}\right)$ of ligand.

\begin{tabular}{llll}
\hline Bond & Bond length & \multicolumn{1}{c}{ Bond } & Bond angle \\
\hline C1-N1 & $1.4165(15)$ & N2-C7-C9 & $111.46(10)$ \\
N3-H & $0.883(19)$ & N2-C7-C8 & $119.56(10)$ \\
N1-N2 & $1.4086(14)$ & C9-C7-C8 & $128.94(11)$ \\
C10-O1 & $1.2441(15)$ & C7-C8-H(8A) & 109.5 \\
C10-N1 & $1.3762(15)$ & C7-C9-C10 & $105.19(10)$ \\
C7-C8 & $1.4940(16)$ & N3-C11-C9 & $117.68(11)$ \\
C9-C11 & $1.3799(16)$ & C11-N3-C18 & $130.59(11)$ \\
C11-N3 & $1.3499(15)$ & C11-N3-H(3A) & $113.7(12)$ \\
C18-N3 & $1.3919(15)$ & C19-S1-C18 & $88.32(6)$ \\
S1-C18 & $1.7316(13)$ & & \\
\hline
\end{tabular}

pseudo nine-membered (N1-N2-C7-C9-C11-N3-H3A-..O1-C10) hydrogen bonded pattern, thus locking the molecular conformation and eliminating conformational flexibility. However, intermolecular interaction involves $\mathrm{C}-\mathrm{H} \cdots \mathrm{O}$ interactions [the

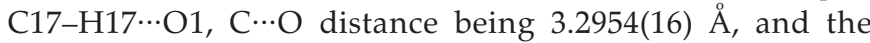
$\mathrm{C}-\mathrm{H} \cdots \mathrm{O}$ angle being $153^{\circ}$, Fig. 2] which stabilize the packing. Table 4 show the intramolecular and intermolecular hydrogen bond geometry, respectively, for the ligand.

\section{Conclusion}

There are three possible tautomers for this broad family of compounds. The Schiff bases produced by the reaction between 4-benzoyl-5-methyl-2-phenyl-2,4-dihydro-pyrazol-3-one (2) and 4-phenyl-thiazol-2-ylamine (3) are shown to exist in the

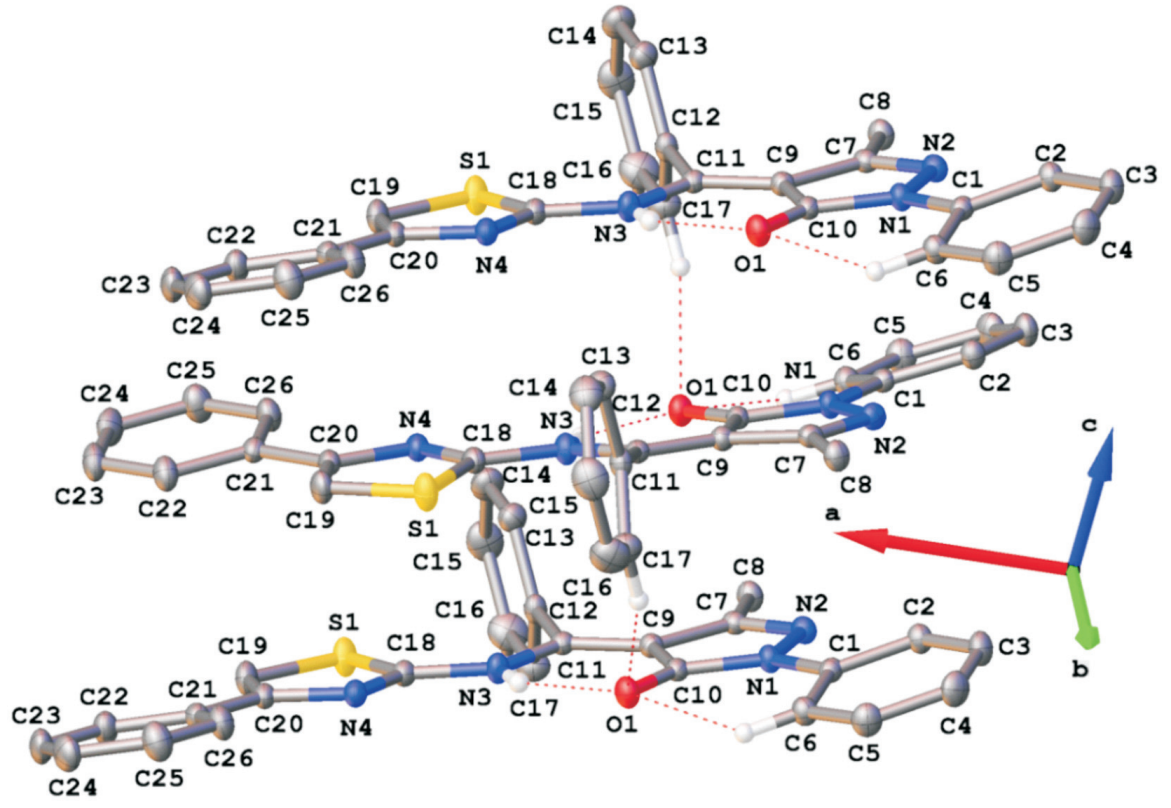

Figure 2 Intramolecular and intermolecular hydrogen-bond for the ligand in the crystal lattice. 
keto-amine (III in Scheme 2) form in deuterated chloroform solutions at room temperature by assigning the NMR signal at $13.73 \mathrm{ppm}$ to the $\mathrm{NH}$, although assignment of this signal to $\mathrm{OH}$ cannot be ruled out if the solid state structural evidence is not considered. The crystal structure of 5-methyl-2-phenyl-4[phenyl-(4-phenyl-thiazol-2-ylamino)-methylene]-2,4dihydro-pyrazol-3-one (4) showed that the synthesized Schiff base exists also in the keto-amine form in the solid state. Furthermore, this solid state structure shows that strong hydrogen bonding between the amine hydrogen and the pyrazolone C10 carbonyl oxygen helps to stabilize the structures of these compounds in the keto-amine form.

\section{Supplementary material}

Copies of ${ }^{1} \mathrm{H}$ NMR, ${ }^{13} \mathrm{C}$ NMR, HSQC, HMBC, COSY and IR spectra are given in the online supplement. CCDC 953343 contains the supplementary crystallographic data for this paper. These data can be obtained free of charge at www.ccdc.cam.ac. $\mathrm{uk} / \mathrm{conts} /$ retrievel.html or from the Cambridge Crystallographic Data Center, 12 Union Road, Cambridge CB2 1EZ, UK; fax +44 1223/336 033; e-mail: deposit@ccdc.ac.uk.

\section{Acknowledgements}

The authors wish to thank Mr. Kamlesh Modi, Prima Chemicals, for providing pyrazolone. The authors are also thankful to Dr. Bernard Owaga from the University of KwaZulu-Natal for assistance with the data collection and refinement, and $C^{*}$ change for financial support.

\section{References}

1 a) D. Gibson, Carbon-bonded beta-diketone complexes, Coord. Chem Rev., 1969, 4, 225-240; b) J.J. Fortman and R.E. Sievers, Optical and geometrical isomerization of $\beta$-diketonate complexes, Coord. Chem. Rev., 1971, 6, 331-375; c) M.A. Elmorsi and A.M. Hassanein, Corrosion inhibition of copper by heterocyclic compounds, Corros. Sci., 1999, $\mathbf{4 1}$ 2337-2352; d) L. Yang, W. Jin and J. Lin, Synthesis, crystal structure and magnetic properties of novel dinuclear complexes of manganese, cobalt and nickel with 4-acetylbispyrazolone, Polyhedron, 2000, 19, 93-98; e) T. Ito, C. Goto and K. Noguchi, Lanthanoid ion-selective solvent polymeric membrane electrode based on 1-phenyl-3methyl-4-octadecanoyl-5-pyrazolone, Anal. Chim. Acta, 2001, 443, 41-51; f) T. Ito, Ion-channel-mimetic sensor for trivalent cations based on self-assembled monolayers of thiol-derivatized 4-acyl5-pyrazolones on gold, J. Electroanal. Chem., 2001, 495, 87-97; g) C. Pettinari, F. Marchetti, C. Santini, R. Pettinari, A. Drozdov, S. Troyanov, G.A. Battiston and R. Gerbasi, Structure and volatility of copper complexes containing pyrazolyl-based ligands, Inorg. Chim. Acta, 2001, 315, 88-95; h) F. Marchetti, C. Pettinari, A. Cingolani, R. Pettinari, M. Rossi and F. Caruso, Organotin(IV) derivatives of novel $\beta$-diketones: Part V. Synthesis and characterization of di- and triorganotin(IV) derivatives of 4-acyl-5-pyrazolones modified in position 3 of the pyrazole. Crystal structure of (1,3-diphenyl-4-benzoylpyrazolon-5-ato)triphenyltin(IV), J. Organomet. Chem, 2002, 645 134-145; i) B.-h. Peng, G.-f. Liu, L. Liu, D.-z. Jia and K.-b. Yu, Crystal structure and spectroscopic study on photochromism of 1-phenyl3-methyl-4-benzal-5-pyrazolone 4-ethylthiosemicarbazone, J. Mol. Struct., 2004, 692, 217-222.

2 a) H. Samelson and A. Lempicki, Fluorescence and lifetimes of Eu chelates, J. Chem. Phys, 1963, 39, 110-112; b) R.G. Charles and E.P. Riedel, Properties of some europium laser chelates derived from benzoyltrifluoroacetone, I. Inorg. Nucl. Chem., 1966, 28, 3005-3018; c) E.W. Berg and J. Jaime Chiang Acosta, Fractional sublimation of the $\beta$-diketone chelates of the lanthanide and related elements, Anal. Chim. Acta, 1968, 40,101-113; d) C.C. Hinckley, Paramagnetic shifts in solutions of cholesterol and the dipyridine adduct of trisdipivalomethanatoeuropium(III). A shift reagent, I. Am. Chem. Soc., 1969, 91, 5160-5162; e) W.D. Horrocks and J.P. Sipe, Lanthanide shift reagents. Survey, J. Am. Chem. Soc., 1971, 93, 6800-6804.

3 a) S. Umetani and $\mathrm{H}$. Freiser, Mixed-ligand chelate extraction of lanthanides with 1-phenyl-3-methyl-4-(trifluoroacetyl)-5-pyrazolone and some phosphine oxide compounds, Inorg. Chem., 1987, 26,
3179-3181; b) A. Tong, Y. Akama and S. Tanaka, Reversed-phase high-performance liquid chromatography of aluminium(III) and indium(III) with 1-phenyl-3-methyl-4-benzoyl-5-pyrazolone, J. Chromatogr. A, 1989, 478, 408-414; c) E.C. Okafor and B.A. Uzoukwu, Extraction of Fe(iii) and U(vi) with 1-phenyl-3-methyl4-acyl-pyrazolones-5 from aqueous-solutions of different acids and complexing agents - separation of Fe(iii) from U(vi), Radiochim. Acta, 1990, 51, 167-172.

4 a) G.A. Chmutova, O.N. Kataeva, H. Ahlbrecht, A.R. Kurbangalieva, A.I. Movchan, A.T.H. Lenstra, H.J. Geise and I.A. Litvinov, Derivatives of 1-phenyl-3-methylpyrazol-2-in-5-thione and their oxygen analogues in the crystalline phase and their tautomeric transformations in solutions and in the gas phase, J. Mol. Struct., 2001, 570, 215-223; b) O.N. Kataeva, A.T. Gubaidullin, I.A. Litvinov, O.A. Lodochnikova, L.R. Islamov, A.I. Movchan and G.A. Chmutova, The structure of 1-phenyl-3-benzoylamino-4-benzoylpyrazol-2-in5-one, J. Mol. Struct., 2002, 610, 175-179; c) W. Holzer, R.M. Claramunt, M. Pérez-Torralba, D. Guggi and T.H. Brehmer, Spiro-fused (C2)-azirino-(C4)-pyrazolones, a new heterocyclic system. Synthesis, spectroscopic studies and X-ray structure analysis, J. Org. Chem., 2003, 68, 7943-7950; d) W. Holzer, K. Hahn, T. Brehmer, R.M. Claramunt and M. Pérez-Torralba, The structure of 4-benzoyl-5-methyl2-phenylpyrazol-3-one oxime and its methyl derivatives, Eur. J. Org. Chem., 2003, 1209-1219.

5 a) K.D. Hargrave, F.K. Hess and J.T. Oliver, N-(4-substitutedthiazolyl)oxamic acid derivatives, new series of potent, orally active antiallergy agents, J. Med. Chem., 1983, 26, 1158-1163; b) F. Haviv, J.D. Ratajczyk, R.W. DeNet, F.A. Kerdesky, R.L. Walters, S.P. Schmidt, J.H. Holms, P.R. Young and G.W. Carter, 3-[1-(2-Benzoxazolyl)hydrazino]propanenitrile derivatives: inhibitors of immune complex induced inflammation, J. Med. Chem., 1988, 31, 1719-1728; c) W.C. Patt, H.W. Hamilton, M.D. Taylor, M.J. Ryan, D.G. Taylor, C.J.C. Connolly, A.M. Doherty, S.R. Klutchko and I. Sircar, Structure-activity relationships of a series of 2-amino-4-thiazolecontaining renin inhibitors, J. Med. Chem., 1992, 35, 2562-2572; d) K. Tsuji and H. Ishikawa, Synthesis and anti-pseudomonal activity of new 2-isocephems with a dihydroxypyridone moiety at C-7, Bioorg. Med. Chem. Lett., 1994, 4, 1601-1606; e) F.W. Bell, A.S. Cantrell, M. Hoegberg, S.R. Jaskunas, N.G. Johansson, C.L. Jordan, M.D. Kinnick, P. Lind and J.M. Morin, Phenethylthiazolethiourea (PETT) compounds, a new class of hiv-1 reverse transcriptase inhibitors. 1. Synthesis and basic structure-activity relationship studies of PETT analogs, J. Med. Chem., 1995, 38, 4929-4936.

6 a) K.T. Joshi, A.M. Pancholi, K.S. Pandya, K.K. Singh and A.S. Thakar, Synthesis, characterization and antimicrobial activity of $\mathrm{Mn}(\mathrm{II})$, $\mathrm{Fe}(\mathrm{II}), \mathrm{Co}(\mathrm{II}), \mathrm{Ni}(\mathrm{II})$ and $\mathrm{Cu}(\mathrm{II})$ complexes of Schiff bases derived from 2-amino-4(4'-methylphenyl)- thiazole and substituted 4-acetyl-1phenyl-3-methyl-2-pyrazolin-5-ones, Asian J. Chem., 2010, 22, 7706-7712; b) A.S. Thakar, K.K. Singh, K.T. Joshi, A.M. Pancholi and K.S. Pandya, Synthesis, characterization and antibacterial activity of Schiff bases and their metal complexes derived from 4-acyl-1phenyl-3-methyl-2-pyrazolin-5-ones and 2-amino-4(4'-methylphenyl)thiazole, E-J. Chem., 2010, 7, 1369-1406; c) A.S. Thakar, K.T. Joshi, K.S. Pandya and A.M. Pancholi, Coordination modes of a Schiff base derived from substituted 2-aminothiazole with chromium(III), manganese(II), iron(II), cobalt(II), nickel(II) and copper(II) metal Ions: synthesis, spectroscopic and antimicrobial studieses, E-J. Chem., 2011, 8, 1750-1764; d) A.S. Thakar, K.S. Pandya, K.T. Joshi and A.M. Pancholi, Synthesis, characterization and antibacterial activity of novel Schiff bases derived from 4-phenyl-2-aminothiazole and their $\mathrm{Mn}(\mathrm{II}), \mathrm{Fe}(\mathrm{II}), \mathrm{Co}(\mathrm{II}), \mathrm{Ni}(\mathrm{II})$ and $\mathrm{Cu}(\mathrm{II})$ metal complexes, E-J. Chem., 2011, 8, 1556-1565.

7 R.N. Jadeja, J.R. Shah, E. Suresh and P. Paul, Synthesis and structural characterization of some Schiff bases derived from 4-[\{(aryl)imino $\}$ ethyl]- 3-methyl-1-(4'-methylphenyl)- 2-pyrazolin-5-one and spectroscopic studies of their $\mathrm{Cu}$ (II) complexes, Polyhedron, 2004, 23, 2465-2474.

8 B.S. Jensen, The Synthesis of 1-phenyl-3-methyl-4-acyl-pyrazolones5, Acta Chem. Scand., 1959, 13, 1668-1670.

9 Bruker-AXS, APEX2, SAINT (Version 6.02) and SADABS Software Reference Manuals, Madison, Wisconsin, USA, 2008.

10 G. Sheldrick, A short history of SHELX, Acta Crystallogr., Sect. A: Found. Crystallogr., 2008, 64, 112-122.

11 L. Farrugia, WinGX suite for small-molecule single-crystal crystallography, J. Appl. Crystallogr., 1999, 32, 837-838. 
12 O.V. Dolomanov, L.J. Bourhis, R.J. Gildea, J. A.K. Howard and H. Puschmann, OLEX2: a complete structure solution, refinement and analysis program, J. Appl. Crystallogr., 2009, 42, 339-341.

13 M. Gowri, C. Jayabalakrishnan, T. Srinivasan and D. Velmurugan, Crystal structure and characterization of novel Schiff base: (Z)-4-((2-hydroxy phenyl)amino)(phenyl)methylene)-3-methyl-1phenyl-1H-pyrazol-5(4H)-one, Mol. Cryst. Liq. Cryst., 2012, 569, 151-161.

14 a) B.T. Thaker, K. Surati, S. Oswal, R.N. Jadeja and V. Gupta, Synthesis, spectral, thermal and crystallographic investigations on oxovanadium(IV) and manganese(III) complexes derived from heterocyclic $\beta$-diketone and 2-amino ethanol, Struct. Chem., 2007, 18, 295-310; b) A.S. Amarasekara, O.S. Owereh, K.A. Lyssenko and T.V. Timofeeva, Structural tautomerism of 4-acylpyrazolone schiff bases and crystal structure of 5-methyl-2-phenyl-4-\{1-[(pyridin-2-ylmethyl) amino]-ethylidene\}-2,4-dihydro-pyrazol-3-one, J. Struct. Chem.,
2009, 50, 1159-1165; c) R. Lu, H. Xia, X. Lu and S. Zhao, (Z)-4-[(2Aminoanilino)(phenyl)methylidene]-3-methyl-1-phenyl-1H-pyraz ol-5(4H)-one, Acta Crystallogr. Sect. E, 2011, 67, o2701; d) D. Zou, X. Lu, S. Zhao and X. Liu, (Z)-4-[(2-Amino-4,5-dichloroanilino)(phenyl) methylidene]-3-methyl-1-phenyl-1H-pyrazol-5(4H)-one, Acta Crystallogr. Sect. E, 2012, 68, o3148.

15 F. Bechtel, J. Gaultier and C. Hauw, 1-Phenyl-5-methyl-3-pyrazolone. $\mathrm{C}_{10} \mathrm{H}_{10} \mathrm{~N}_{2} \mathrm{O}$, Cryst. Struct. Commun., 1973, 2, 473-476.

16 F. Bechtel, J. Gaultier and C. Hauw, 1-Phenyl-3-methyl-5-pyrazolone. $\mathrm{C}_{10} \mathrm{H}_{10} \mathrm{~N}_{2} \mathrm{O}$, Cryst. Struct. Commun., 1973, 2, 469-472.

17 L. Liu, D.-Z. Jia, Y.-L. Ji and K.-B. Yu, Synthesis, structure and photochromic properties of 4-acyl pyrazolone derivants, J. Photochem. Photobiol. A, 2003, 154, 117-122.

18 C. Arici, M.N. Tahir, D. Ulku and O. Atakol, 4-Chloro-2-(4-oxopent-2-en-2-ylamino)phenol, Acta Crystallogr., Sect. C, 1999, 55, $1691-1692$. 


\section{Supporting Information}

Isolation, characterization and X-ray structure determination of Schiff base ligand: 5Methyl-2-phenyl-4-[phenyl-(4-phenyl-thiazol-2-ylamino)-methylene]-2,4-dihydro-pyrazol3-one

Amit S. Thakar ${ }^{1}$, Holger B. Friedrich ${ }^{1}$, Krishnalal T. Joshi ${ }^{2}$ and Glenn E.M. Maguire ${ }^{1 *}$

${ }^{1}$ School of Chemistry and Physics, University of KwaZulu-Natal, Durban, 4000, South Africa,

${ }^{2}$ Department of Chemistry, Navjivan Science College, Dahod, Gujarat, 389 151, India

*E-mail: maguireg@ukzn.ac.za; Tel.: +27 31260 1113; Fax: +27 312603091

\section{Table of content}

1. Experimental S3

$\begin{array}{ll}\text { 1.1 Materials } & \text { S3 }\end{array}$

$\begin{array}{ll}\text { 1.2 Physical measurements } & \text { S3 }\end{array}$

1.3 Synthesis of Schiff base ligand $\quad$ S3

2. Scheme S1. Synthetic pathway of Schiff base ligand $\quad$ S4

3. Figure S1. ${ }^{1} \mathrm{H}$ NMR spectra of Schiff base ligand S5

4. Figure S2. ${ }^{13} \mathrm{C}$ NMR spectra of Schiff base ligand S5

5. Figure S3. HSQC spectra of Schiff base ligand S6

6. Figure S4. HMBC spectra of Schiff base ligand S6

7. Figure S5. COSY spectra of Schiff base ligand $\quad$ S7

8. Figure S6. IR spectra of Schiff base ligand

9. X-ray crystallography data of Schiff base ligand S8

Figure S7. ORTEP diagram showing atom numbering scheme S8

$\begin{array}{ll}\text { Table S1. Crystal data and structure refinement } & \text { S8 }\end{array}$

Table S2. Atomic coordinates and equivalent isotropic displacement parameters S9

Table S3. Bond lengths $[\AA]$ and angles $\left[{ }^{\circ}\right] \quad$ S10 
Table S4. Anisotropic displacement parameters

Table S5. Hydrogen coordinates and isotropic displacement parameters

\section{Experimental}

\subsection{Materials}

The compound 5-methyl-2-phenyl-2,4-dihydro-pyrazol-3-one 1 was obtained from Prima chemicals, Ahmedabad, India. Methanol, dioxane, was obtained from SD's fine chemical Ltd., India. Absolute alcohol was obtained from Baroda Chem. Industry Ltd. and was used after distillation. Calcium hydroxide and benzoyl chloride were obtained from Samir Tech. Chem. Pvt. Ltd. All the chemicals used were of AR grade. Solvents used in this study were purified following the standard procedures.

\subsection{Physical measurements}

The elemental analysis was obtained from Flash Elemental Analyzer-1112. Infrared spectra (IR) were measured using a Perkin Elmer Precisely Spectrometer100 FT-IR spectrometer. 1H and 13C NMR spectra were measured at 400.22 and $100.63 \mathrm{MHz}$, respectively, with a Bruker Avance III $400 \mathrm{MHz}$ spectrophotometer by using TMS (tetramethylsilane) as the internal reference. Melting point is recorded on an Ernst Leitz Wetzlar hot stage melting point apparatus. Reactions were monitored by thin layer chromatography (TLC) on aluminum-backed plates coated with Merck Kieselgel 60 F254 silica gel. TLC plates were visualized by UV radiation at a wavelength of $254 \mathrm{~nm}$.

\subsection{Synthesis of Schiff base ligand}

5-Methyl-2-phenyl-2,4-dihydro-pyrazol-3-one 1 (2 g, $11.5 \mathrm{mmol}$ ) was dissolved in hot dioxane $(20 \mathrm{~mL})$ in a flask equipped with a stirrer, separating funnel and reflux condenser. Calcium hydroxide ( $1.7 \mathrm{~g}, 23 \mathrm{mmol})$ was added to this solution, followed by benzoyl chloride (3.23 $\mathrm{g}$, $11.5 \mathrm{mmol}$ ) added drop wise with precaution, as this reaction was exothermic. During this addition the whole mass was converted into a thick paste. After the complete addition, the reaction mixture was refluxed for half an hour and then it was poured into dilute hydrochloric acid (50 mL, 2 M). The colored crystals of 4-benzoyl-5-methyl-2-phenyl-2,4-dihydro-pyrazol-3- 
one 2 thus obtained were separated by filtration and recrystallized from n-hexane to give a bright yellow crystalline solid $(2.5 \mathrm{~g}, 80 \%)$.

A solution of 4-benzoyl-5-methyl-2-phenyl-2,4-dihydro-pyrazol-3-one 2 (1 g, $3.6 \mathrm{mmol})$ in methanol $(30 \mathrm{~mL})$ was added to a another solution of 4-phenyl-thiazol-2-ylamine 3 (0.63 g, 3.6 $\mathrm{mmol})$ in methanol $(20 \mathrm{~mL})$ under an inert atmosphere. The reaction mixture was refluxed for three hours. Completion of the reaction was monitored by TLC using hexane/ethyl acetate $(8: 2)$. The reaction was allowed to cool to room temperature and stirred overnight. A yellow precipitate formed which was then filtered and washed with methanol $(10 \mathrm{~mL})$. The crude product, purified by crystallization from ethanol to give brown crystals of the desired product 5-Methyl-2-phenyl4-[phenyl-(4-phenyl-thiazol-2-ylamino)-methylene]-2,4-dihydro-pyrazol-3-one 4 (1.2 g, 77\% yield).

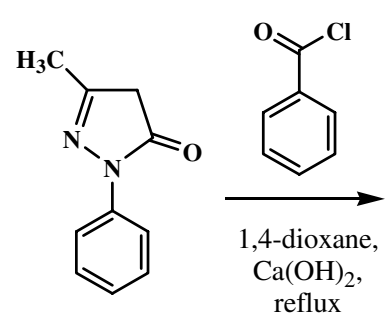

1<smiles>CC1=NN(c2ccccc2)C(=O)C1C(=O)c1ccccc1</smiles>

2

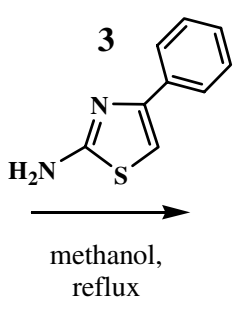

reflux<smiles>CC1=NN(c2ccccc2)C(=O)/C1=C(/Nc1nc(-c2ccccc2)cs1)c1ccccc1</smiles>

4

Scheme S1. Synthetic pathway of the Schiff base ligand 
Fig. $1{ }^{1} \mathrm{H}$ NMR spectra of Schiff base ligand

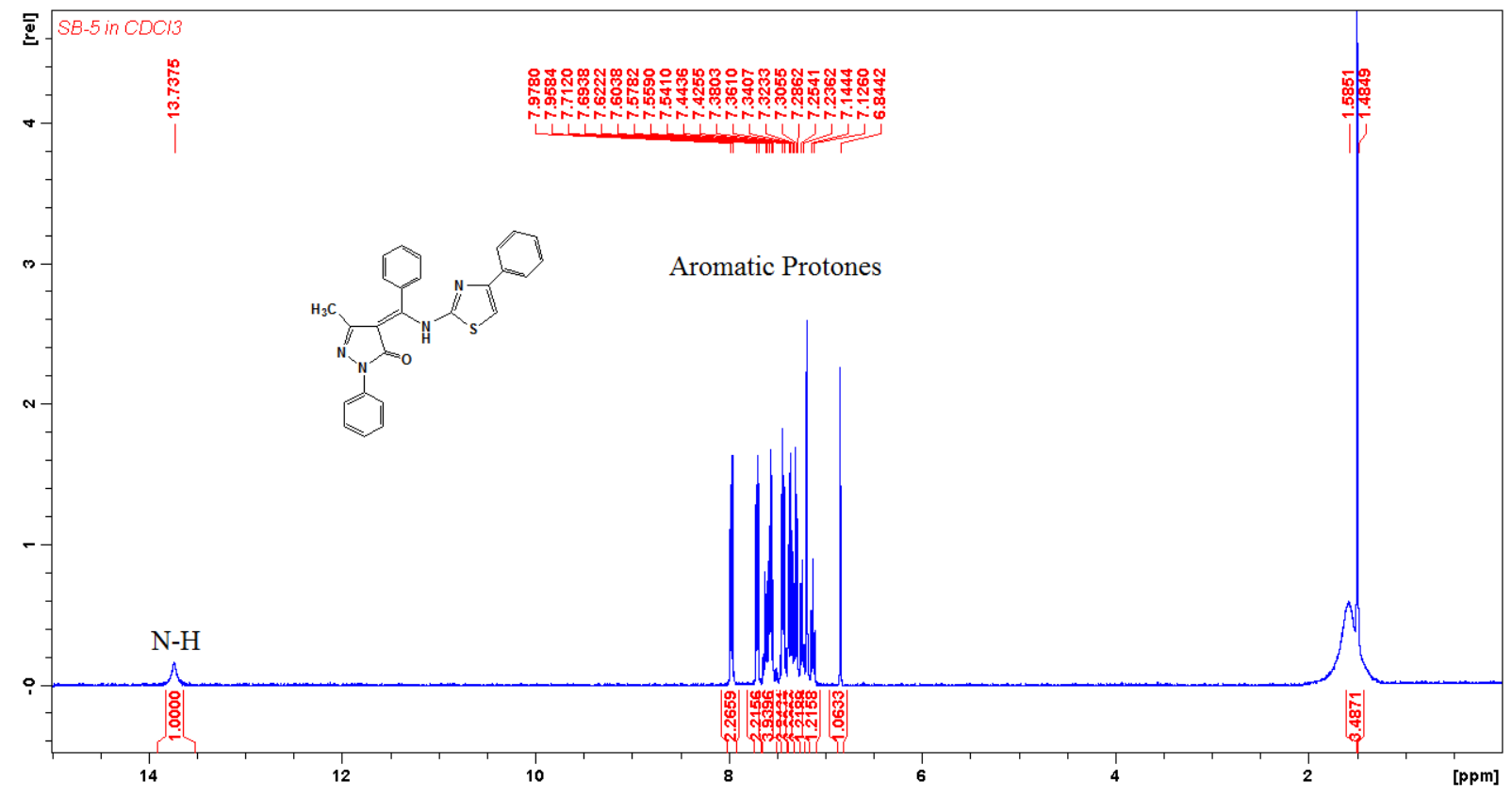

Fig. S2 ${ }^{13} \mathrm{C}$ NMR spectra of Schiff base ligand

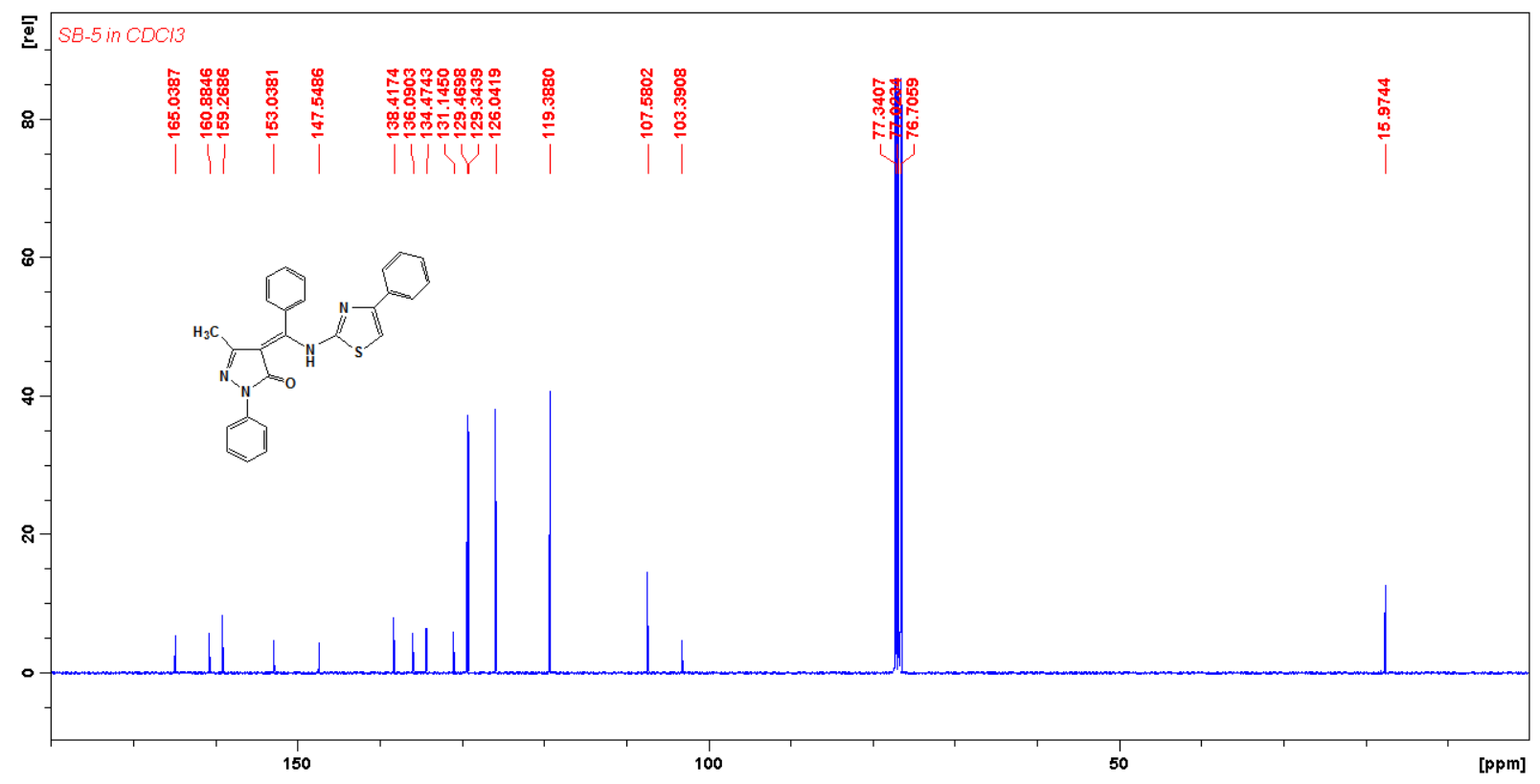


Fig. S3 ${ }^{1} \mathrm{H}^{-13} \mathrm{C}$ HSQC spectra of Schiff base ligand

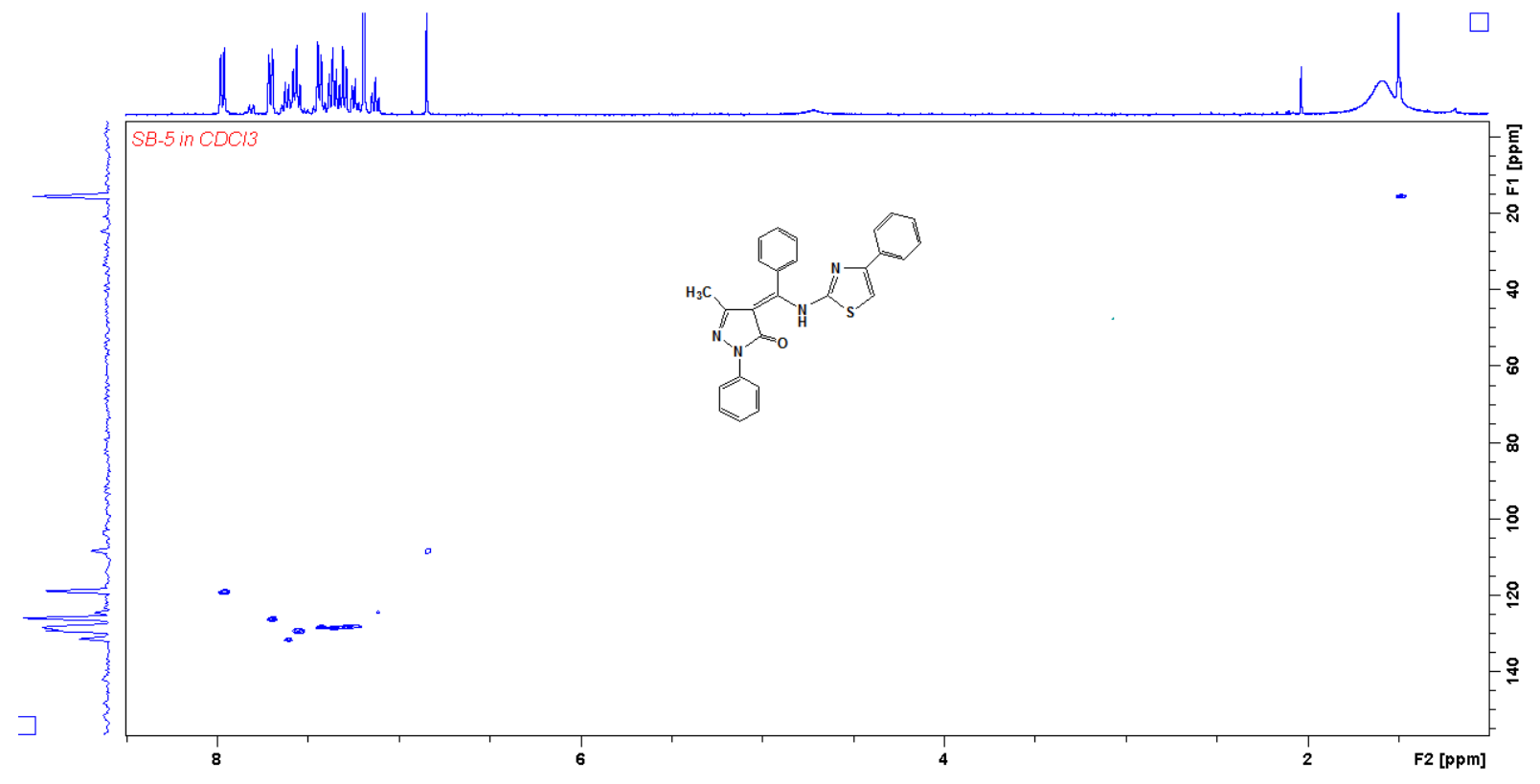

Fig. S4 ${ }^{1} \mathrm{H}-{ }^{13} \mathrm{C}$ HMBC spectra of Schiff base ligand

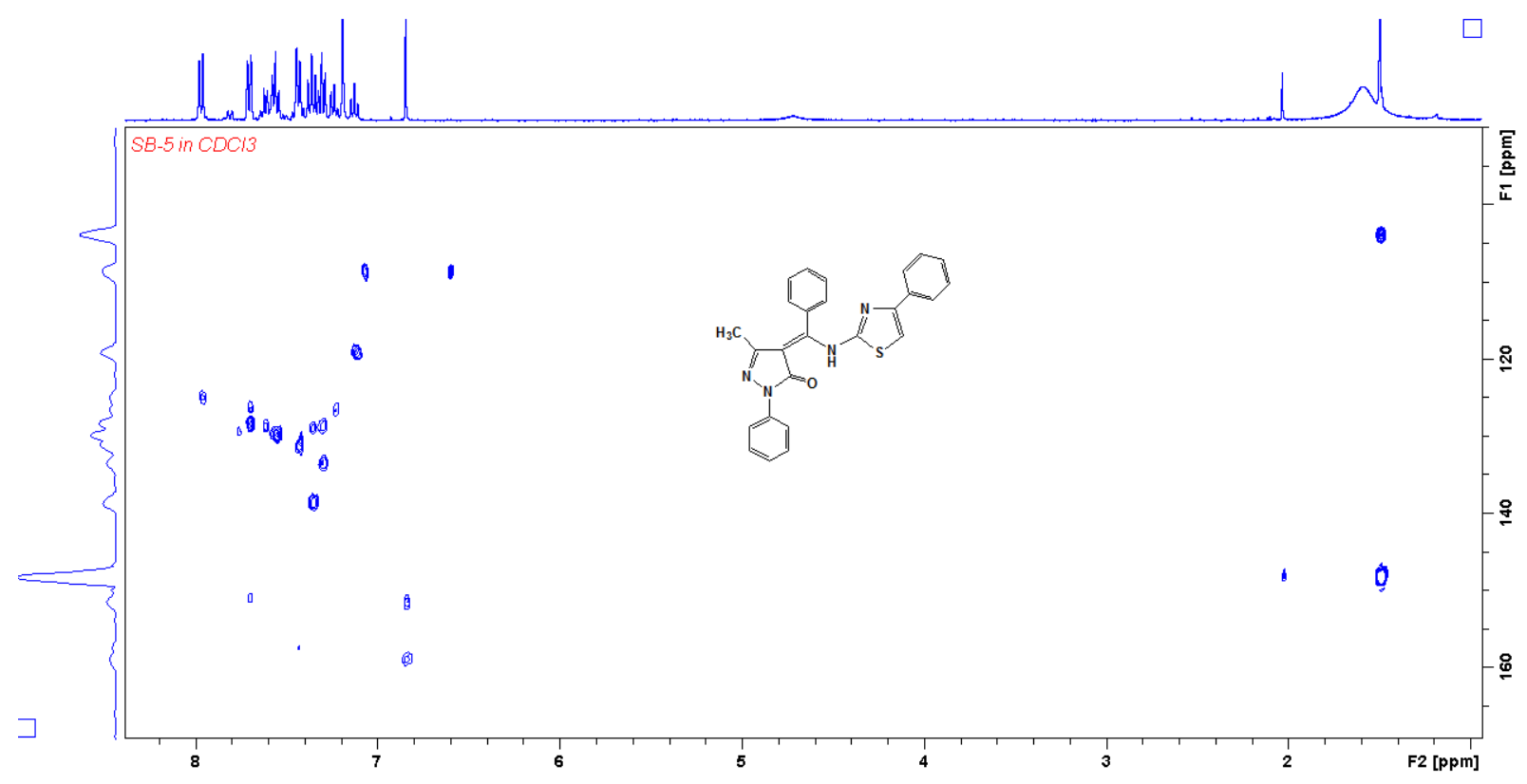


Fig. S5 COSY spectra of Schiff base ligand

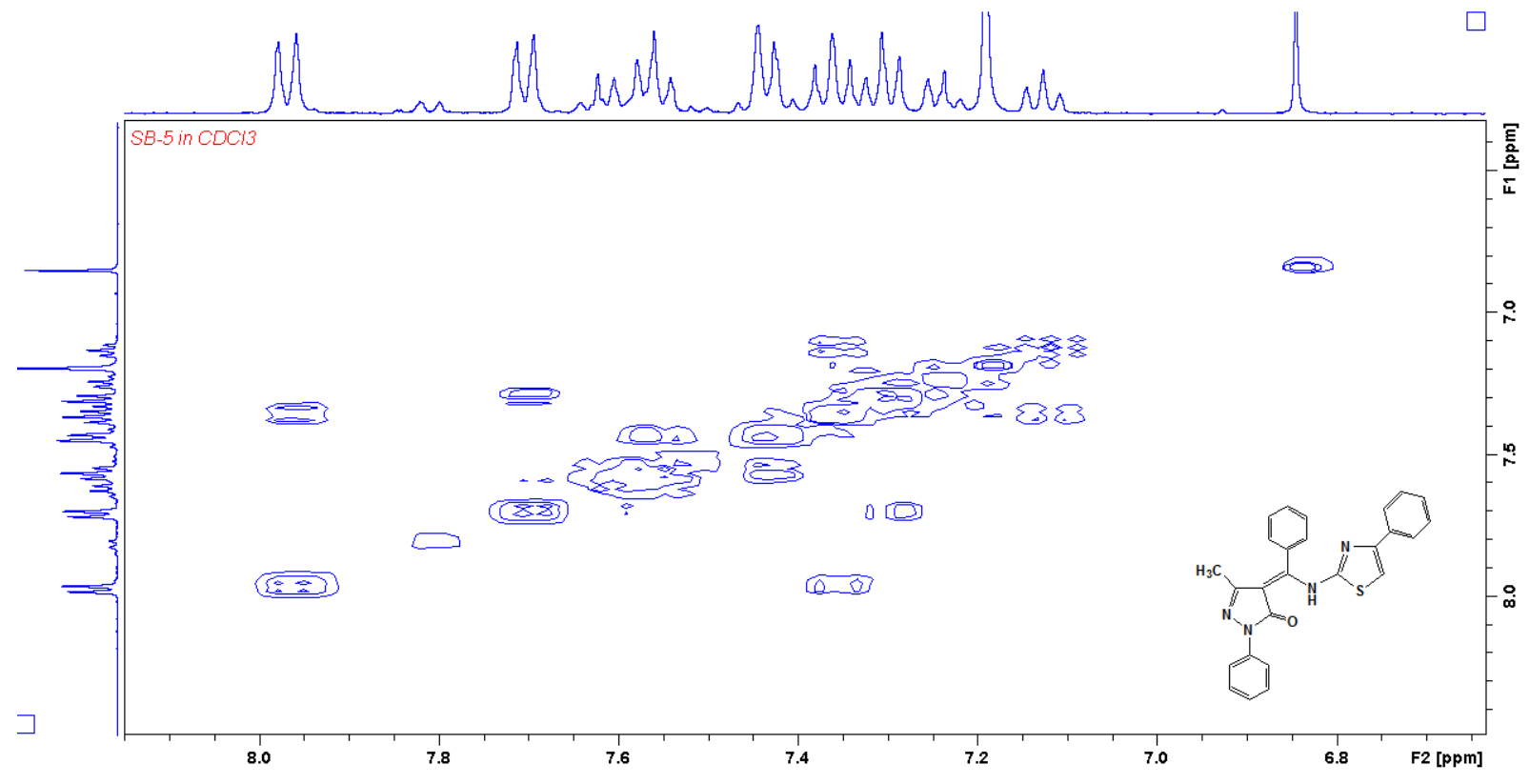

Fig. S6 IR spectra of Schiff base ligand

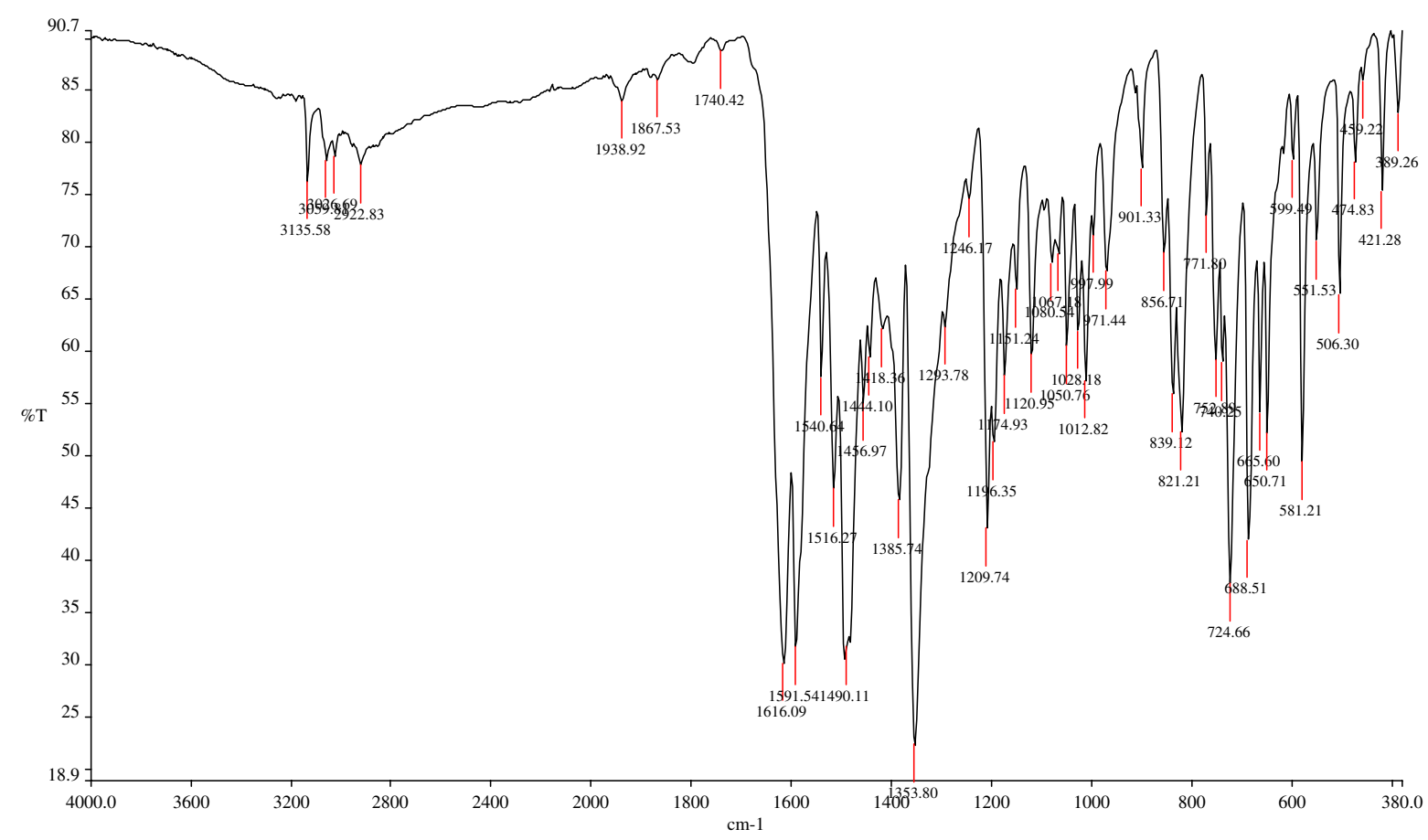




\section{X-ray crystallography data of Schiff base ligand}

Fig. S7 ORTEP diagram showing atom numbering scheme.

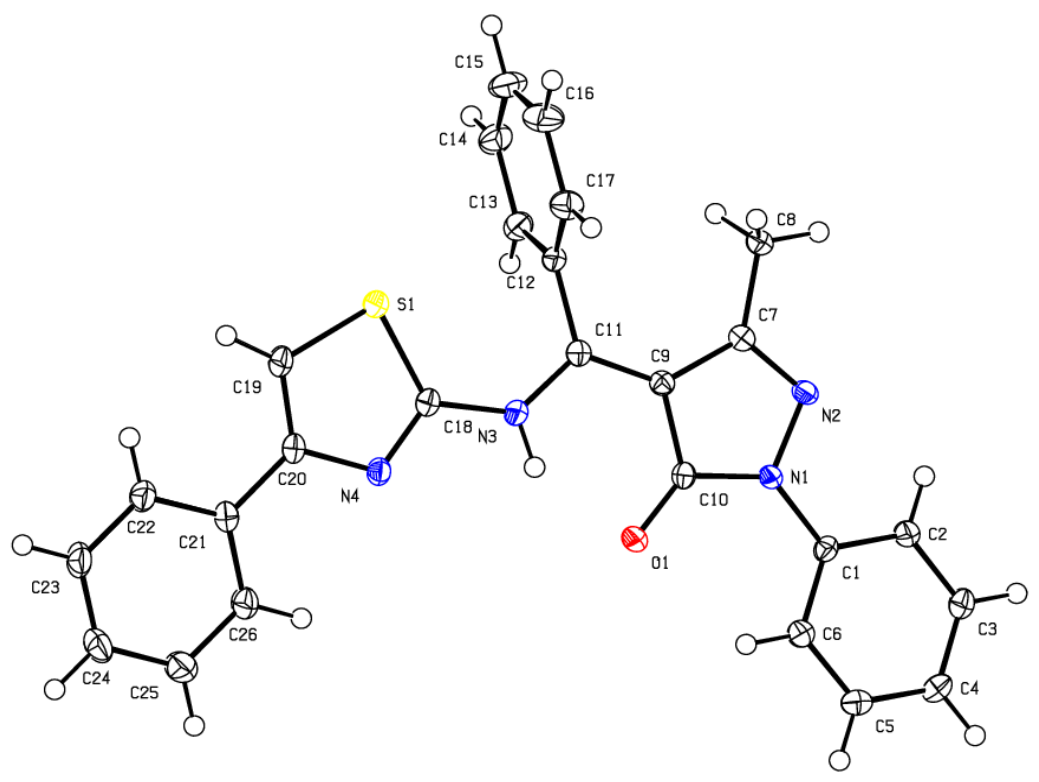

Table S1 Crystal data and structure refinement

Identification code

Empirical formula

Formula weight

Temperature

Wavelength

Crystal system

Space group

Unit cell dimensions

$\mathrm{b}=21.2378(4) \AA$

$c=7.22470(10) \AA$

Volume

$\mathrm{Z}$

Density (calculated) 13bo_hbf_at3_0ma

C26 H20 N4 O S

436.52

173(2) K

$0.71073 \AA$

Monoclinic

P21/c

$\mathrm{a}=13.9867(3) \AA \quad \square=90^{\circ}$.

$\square=95.7990(10)^{\circ}$.

$\square=90^{\circ}$.

2135.09(7) $\AA^{3}$

4

$1.358 \mathrm{Mg} / \mathrm{m}^{3}$ 


$\begin{array}{ll}\text { Absorption coefficient } & 0.179 \mathrm{~mm}^{-1} \\ \mathrm{~F}(000) & 912 \\ \text { Crystal size } & 0.46 \times 0.25 \times 0.23 \mathrm{~mm}^{3} \\ \text { Theta range for data collection } & 1.75 \text { to } 28.41^{\circ} . \\ \text { Index ranges } & -17<=\mathrm{h}<=18,-28<=\mathrm{k}<=27,-9<=1<=9 \\ \text { Reflections collected } & 58780 \\ \text { Independent reflections } & 5358[\mathrm{R}(\mathrm{int})=0.0260] \\ \text { Completeness to theta }=28.41^{\circ} & 99.9 \% \\ \text { Absorption correction } & \mathrm{Semi}-\mathrm{empirical} \text { from equivalents } \\ \text { Max. and min. transmission } & 0.9600 \text { and } 0.9223 \\ \text { Refinement method } & \text { Full-matrix least-squares on } \mathrm{F}^{2} \\ \text { Data / restraints / parameters } & 5358 / 0 / 294 \\ \text { Goodness-of-fit on } \mathrm{F}^{2} & 1.035 \\ \text { Final R indices [I }>2 \text { sigma(I)] } & \mathrm{R} 1=0.0373, \text { wR2 }=0.0913 \\ \text { R indices (all data) } & \mathrm{R} 1=0.0476, \text { wR2 }=0.0978 \\ \text { Largest diff. peak and hole } & 0.572 \text { and }-0.285 \text { e. } \AA^{-3}\end{array}$

Table S2 Atomic coordinates ( x 104) and equivalent isotropic displacement parameters $\left(\AA^{2} \mathrm{x}\right.$ $\left.10^{3}\right)$

$\mathrm{U}(\mathrm{eq})$ is defined as one third of the trace of the orthogonalized $\mathrm{Uij}^{\mathrm{ij}}$ tensor.

\begin{tabular}{lrrrr}
\hline & $\mathrm{x}$ & $\mathrm{y}$ & $\mathrm{z}$ & $\mathrm{U}(\mathrm{eq})$ \\
\hline $\mathrm{C}(1)$ & $376(1)$ & $6621(1)$ & $2484(2)$ & $15(1)$ \\
$\mathrm{C}(2)$ & $-459(1)$ & $6706(1)$ & $3370(2)$ & $18(1)$ \\
$\mathrm{C}(3)$ & $-1022(1)$ & $6188(1)$ & $3708(2)$ & $22(1)$ \\
$\mathrm{C}(4)$ & $-769(1)$ & $5587(1)$ & $3187(2)$ & $24(1)$ \\
$\mathrm{C}(5)$ & $62(1)$ & $5507(1)$ & $2312(2)$ & $23(1)$ \\
$\mathrm{C}(6)$ & $637(1)$ & $6018(1)$ & $1950(2)$ & $19(1)$ \\
$\mathrm{C}(7)$ & $1232(1)$ & $8163(1)$ & $2131(2)$ & $15(1)$ \\
$\mathrm{C}(8)$ & $1029(1)$ & $8851(1)$ & $2265(2)$ & $19(1)$ \\
$\mathrm{C}(9)$ & $2077(1)$ & $7856(1)$ & $1590(2)$ & $15(1)$ \\
$\mathrm{C}(10)$ & $1861(1)$ & $7184(1)$ & $1623(2)$ & $15(1)$
\end{tabular}




\begin{tabular}{lrrrr}
$\mathrm{C}(11)$ & $2955(1)$ & $8089(1)$ & $1200(2)$ & $15(1)$ \\
$\mathrm{C}(12)$ & $3212(1)$ & $8770(1)$ & $1367(2)$ & $17(1)$ \\
$\mathrm{C}(13)$ & $3678(1)$ & $8985(1)$ & $3045(2)$ & $21(1)$ \\
$\mathrm{C}(14)$ & $3920(1)$ & $9616(1)$ & $3238(2)$ & $27(1)$ \\
$\mathrm{C}(15)$ & $3704(1)$ & $10030(1)$ & $1773(2)$ & $31(1)$ \\
$\mathrm{C}(16)$ & $3240(1)$ & $9817(1)$ & $107(2)$ & $31(1)$ \\
$\mathrm{C}(17)$ & $2993(1)$ & $9185(1)$ & $-107(2)$ & $24(1)$ \\
$\mathrm{C}(18)$ & $4552(1)$ & $7766(1)$ & $276(2)$ & $17(1)$ \\
$\mathrm{C}(19)$ & $6097(1)$ & $8094(1)$ & $-555(2)$ & $22(1)$ \\
$\mathrm{C}(20)$ & $5977(1)$ & $7461(1)$ & $-442(2)$ & $17(1)$ \\
$\mathrm{C}(21)$ & $6703(1)$ & $6979(1)$ & $-743(2)$ & $18(1)$ \\
$\mathrm{C}(22)$ & $7573(1)$ & $7149(1)$ & $-1409(2)$ & $23(1)$ \\
$\mathrm{C}(23)$ & $8260(1)$ & $6699(1)$ & $-1700(2)$ & $26(1)$ \\
$\mathrm{C}(24)$ & $8087(1)$ & $6071(1)$ & $-1342(2)$ & $28(1)$ \\
$\mathrm{C}(25)$ & $7226(1)$ & $5894(1)$ & $-686(2)$ & $29(1)$ \\
$\mathrm{C}(26)$ & $6538(1)$ & $6345(1)$ & $-390(2)$ & $23(1)$ \\
$\mathrm{N}(1)$ & $947(1)$ & $7154(1)$ & $2167(1)$ & $15(1)$ \\
$\mathrm{N}(2)$ & $573(1)$ & $7757(1)$ & $2469(1)$ & $16(1)$ \\
$\mathrm{N}(3)$ & $3621(1)$ & $7672(1)$ & $745(2)$ & $18(1)$ \\
$\mathrm{N}(4)$ & $5083(1)$ & $7275(1)$ & $28(2)$ & $17(1)$ \\
$\mathrm{O}(1)$ & $2388(1)$ & $6734(1)$ & $1290(1)$ & $19(1)$ \\
$\mathrm{S}(1)$ & $5081(1)$ & $8489(1)$ & $-58(1)$ & $23(1)$ \\
\hline
\end{tabular}

Table S3 Bond lengths [ $\mathrm{\AA}]$ and angles $\left[{ }^{\circ}\right]$

\begin{tabular}{ll}
\hline $\mathrm{C}(1)-\mathrm{C}(6)$ & $1.3957(17)$ \\
$\mathrm{C}(1)-\mathrm{C}(2)$ & $1.3982(17)$ \\
$\mathrm{C}(1)-\mathrm{N}(1)$ & $1.4165(15)$ \\
$\mathrm{C}(2)-\mathrm{C}(3)$ & $1.3892(17)$ \\
$\mathrm{C}(2)-\mathrm{H}(2)$ & 0.9500 \\
$\mathrm{C}(3)-\mathrm{C}(4)$ & $1.3865(19)$ \\
$\mathrm{C}(3)-\mathrm{H}(3)$ & 0.9500 \\
$\mathrm{C}(4)-\mathrm{C}(5)$ & $1.3879(19)$ \\
$\mathrm{C}(4)-\mathrm{H}(4)$ & 0.9500 \\
$\mathrm{C}(5)-\mathrm{C}(6)$ & $1.3918(18)$ \\
$\mathrm{C}(5)-\mathrm{H}(5)$ & 0.9500 \\
$\mathrm{C}(6)-\mathrm{H}(6)$ & 0.9500 \\
$\mathrm{C}(7)-\mathrm{N}(2)$ & $1.3038(16)$ \\
$\mathrm{C}(7)-\mathrm{C}(9)$ & $1.4390(16)$ \\
$\mathrm{C}(7)-\mathrm{C}(8)$ & $1.4940(16)$ \\
$\mathrm{C}(8)-\mathrm{H}(8 \mathrm{~A})$ & 0.9800 \\
$\mathrm{C}(8)-\mathrm{H}(8 \mathrm{~B})$ & 0.9800
\end{tabular}




\begin{tabular}{|c|c|}
\hline $\mathrm{C}(8)-\mathrm{H}(8 \mathrm{C})$ & 0.9800 \\
\hline $\mathrm{C}(9)-\mathrm{C}(11)$ & $1.3799(16)$ \\
\hline C(9)-C(10) & $1.4596(16)$ \\
\hline $\mathrm{C}(10)-\mathrm{O}(1)$ & $1.2441(15)$ \\
\hline $\mathrm{C}(10)-\mathrm{N}(1)$ & $1.3762(15)$ \\
\hline $\mathrm{C}(11)-\mathrm{N}(3)$ & $1.3499(15)$ \\
\hline $\mathrm{C}(11)-\mathrm{C}(12)$ & $1.4928(17)$ \\
\hline $\mathrm{C}(12)-\mathrm{C}(17)$ & $1.3917(18)$ \\
\hline $\mathrm{C}(12)-\mathrm{C}(13)$ & $1.3933(18)$ \\
\hline $\mathrm{C}(13)-\mathrm{C}(14)$ & $1.3875(18)$ \\
\hline $\mathrm{C}(13)-\mathrm{H}(13)$ & 0.9500 \\
\hline $\mathrm{C}(14)-\mathrm{C}(15)$ & $1.385(2)$ \\
\hline $\mathrm{C}(14)-\mathrm{H}(14)$ & 0.9500 \\
\hline $\mathrm{C}(15)-\mathrm{C}(16)$ & $1.384(2)$ \\
\hline $\mathrm{C}(15)-\mathrm{H}(15)$ & 0.9500 \\
\hline$C(16)-C(17)$ & $1.391(2)$ \\
\hline $\mathrm{C}(16)-\mathrm{H}(16)$ & 0.9500 \\
\hline $\mathrm{C}(17)-\mathrm{H}(17)$ & 0.9500 \\
\hline $\mathrm{C}(18)-\mathrm{N}(4)$ & $1.3047(16)$ \\
\hline $\mathrm{C}(18)-\mathrm{N}(3)$ & $1.3919(15)$ \\
\hline $\mathrm{C}(18)-\mathrm{S}(1)$ & $1.7316(13)$ \\
\hline$C(19)-C(20)$ & $1.3593(18)$ \\
\hline $\mathrm{C}(19)-\mathrm{S}(1)$ & $1.7191(13)$ \\
\hline C(19)-H(19) & 0.9500 \\
\hline $\mathrm{C}(20)-\mathrm{N}(4)$ & $1.3864(15)$ \\
\hline $\mathrm{C}(20)-\mathrm{C}(21)$ & $1.4726(17)$ \\
\hline$C(21)-C(26)$ & $1.3930(18)$ \\
\hline $\mathrm{C}(21)-\mathrm{C}(22)$ & $1.3998(17)$ \\
\hline $\mathrm{C}(22)-\mathrm{C}(23)$ & $1.3858(19)$ \\
\hline $\mathrm{C}(22)-\mathrm{H}(22)$ & 0.9500 \\
\hline $\mathrm{C}(23)-\mathrm{C}(24)$ & $1.384(2)$ \\
\hline $\mathrm{C}(23)-\mathrm{H}(23)$ & 0.9500 \\
\hline $\mathrm{C}(24)-\mathrm{C}(25)$ & $1.3897(19)$ \\
\hline $\mathrm{C}(24)-\mathrm{H}(24)$ & 0.9500 \\
\hline $\mathrm{C}(25)-\mathrm{C}(26)$ & $1.3888(19)$ \\
\hline $\mathrm{C}(25)-\mathrm{H}(25)$ & 0.9500 \\
\hline $\mathrm{C}(26)-\mathrm{H}(26)$ & 0.9500 \\
\hline $\mathrm{N}(1)-\mathrm{N}(2)$ & $1.4086(14)$ \\
\hline $\mathrm{N}(3)-\mathrm{H}(3 \mathrm{~A})$ & $0.883(19)$ \\
\hline$C(6)-C(1)-C(2)$ & $119.87(11)$ \\
\hline $\mathrm{C}(6)-\mathrm{C}(1)-\mathrm{N}(1)$ & $121.35(11)$ \\
\hline $\mathrm{C}(2)-\mathrm{C}(1)-\mathrm{N}(1)$ & $118.78(11)$ \\
\hline $\mathrm{C}(3)-\mathrm{C}(2)-\mathrm{C}(1)$ & $119.56(12)$ \\
\hline $\mathrm{C}(3)-\mathrm{C}(2)-\mathrm{H}(2)$ & 120.2 \\
\hline $\mathrm{C}(1)-\mathrm{C}(2)-\mathrm{H}(2)$ & 120.2 \\
\hline
\end{tabular}




$\begin{array}{ll}\mathrm{C}(4)-\mathrm{C}(3)-\mathrm{C}(2) & 121.02(12) \\ \mathrm{C}(4)-\mathrm{C}(3)-\mathrm{H}(3) & 119.5 \\ \mathrm{C}(2)-\mathrm{C}(3)-\mathrm{H}(3) & 119.5 \\ \mathrm{C}(3)-\mathrm{C}(4)-\mathrm{C}(5) & 119.07(12) \\ \mathrm{C}(3)-\mathrm{C}(4)-\mathrm{H}(4) & 120.5 \\ \mathrm{C}(5)-\mathrm{C}(4)-\mathrm{H}(4) & 120.5 \\ \mathrm{C}(4)-\mathrm{C}(5)-\mathrm{C}(6) & 121.01(12) \\ \mathrm{C}(4)-\mathrm{C}(5)-\mathrm{H}(5) & 119.5 \\ \mathrm{C}(6)-\mathrm{C}(5)-\mathrm{H}(5) & 119.5 \\ \mathrm{C}(5)-\mathrm{C}(6)-\mathrm{C}(1) & 119.48(12) \\ \mathrm{C}(5)-\mathrm{C}(6)-\mathrm{H}(6) & 120.3 \\ \mathrm{C}(1)-\mathrm{C}(6)-\mathrm{H}(6) & 120.3 \\ \mathrm{~N}(2)-\mathrm{C}(7)-\mathrm{C}(9) & 111.46(10) \\ \mathrm{N}(2)-\mathrm{C}(7)-\mathrm{C}(8) & 119.56(10) \\ \mathrm{C}(9)-\mathrm{C}(7)-\mathrm{C}(8) & 128.94(11) \\ \mathrm{C}(7)-\mathrm{C}(8)-\mathrm{H}(8 \mathrm{~A}) & 109.5 \\ \mathrm{C}(7)-\mathrm{C}(8)-\mathrm{H}(8 \mathrm{~B}) & 109.5 \\ \mathrm{H}(8 \mathrm{~A})-\mathrm{C}(8)-\mathrm{H}(8 \mathrm{~B}) & 109.5 \\ \mathrm{C}(7)-\mathrm{C}(8)-\mathrm{H}(8 \mathrm{C}) & 109.5 \\ \mathrm{H}(8 \mathrm{~A})-\mathrm{C}(8)-\mathrm{H}(8 \mathrm{C}) & 109.5 \\ \mathrm{H}(8 \mathrm{~B})-\mathrm{C}(8)-\mathrm{H}(8 \mathrm{C}) & 109.5 \\ \mathrm{C}(11)-\mathrm{C}(9)-\mathrm{C}(7) & 131.68(11) \\ \mathrm{C}(11)-\mathrm{C}(9)-\mathrm{C}(10) & 123.04(11) \\ \mathrm{C}(7)-\mathrm{C}(9)-\mathrm{C}(10) & 105.19(10) \\ \mathrm{O}(1)-\mathrm{C}(10)-\mathrm{N}(1) & 127.27(11) \\ \mathrm{O}(1)-\mathrm{C}(10)-\mathrm{C}(9) & 128.22(11) \\ \mathrm{N}(1)-\mathrm{C}(10)-\mathrm{C}(9) & 104.48(10) \\ \mathrm{N}(3)-\mathrm{C}(11)-\mathrm{C}(9) & 117.68(11) \\ \mathrm{N}(3)-\mathrm{C}(11)-\mathrm{C}(12) & 119.26(10) \\ \mathrm{C}(9)-\mathrm{C}(11)-\mathrm{C}(12) & 122.96(11) \\ \mathrm{C}(17)-\mathrm{C}(12)-\mathrm{C}(13) & 120.46(12) \\ \mathrm{C}(17)-\mathrm{C}(12)-\mathrm{C}(11) & 121.20(11) \\ \mathrm{C}(13)-\mathrm{C}(12)-\mathrm{C}(11) & 118.34(11) \\ \mathrm{C}(14)-\mathrm{C}(13)-\mathrm{C}(12) & 119.39(12) \\ \mathrm{C}(14)-\mathrm{C}(13)-\mathrm{H}(13) & 120.3 \\ \mathrm{C}(12)-\mathrm{C}(13)-\mathrm{H}(13) & 120.3 \\ \mathrm{C}(15)-\mathrm{C}(14)-\mathrm{C}(13) & 120.33(13) \\ \mathrm{C}(15)-\mathrm{C}(14)-\mathrm{H}(14) & 119.8 \\ \mathrm{C}(13)-\mathrm{C}(14)-\mathrm{H}(14) & 119.8 \\ \mathrm{C}(16)-\mathrm{C}(15)-\mathrm{C}(14) & 120.21(13) \\ \mathrm{C}(16)-\mathrm{C}(15)-\mathrm{H}(15) & 119.9 \\ \mathrm{C}(14)-\mathrm{C}(15)-\mathrm{H}(15) & 119.9 \\ \mathrm{C}(15)-\mathrm{C}(16)-\mathrm{C}(17) & 120.12(13) \\ \mathrm{C}(15)-\mathrm{C}(16)-\mathrm{H}(16) & 119.9 \\ \mathrm{C}(17)-\mathrm{C}(16)-\mathrm{H}(16) & 119.9 \\ \mathrm{C}(16)-\mathrm{C}(17)-\mathrm{C}(12) & 119.48(13) \\ & \\ & \end{array}$




\begin{tabular}{ll}
$\mathrm{C}(16)-\mathrm{C}(17)-\mathrm{H}(17)$ & 120.3 \\
$\mathrm{C}(12)-\mathrm{C}(17)-\mathrm{H}(17)$ & 120.3 \\
$\mathrm{~N}(4)-\mathrm{C}(18)-\mathrm{N}(3)$ & $118.55(11)$ \\
$\mathrm{N}(4)-\mathrm{C}(18)-\mathrm{S}(1)$ & $115.67(9)$ \\
$\mathrm{N}(3)-\mathrm{C}(18)-\mathrm{S}(1)$ & $125.77(9)$ \\
$\mathrm{C}(20)-\mathrm{C}(19)-\mathrm{S}(1)$ & $111.16(9)$ \\
$\mathrm{C}(20)-\mathrm{C}(19)-\mathrm{H}(19)$ & 124.4 \\
$\mathrm{~S}(1)-\mathrm{C}(19)-\mathrm{H}(19)$ & 124.4 \\
$\mathrm{C}(19)-\mathrm{C}(20)-\mathrm{N}(4)$ & $114.61(11)$ \\
$\mathrm{C}(19)-\mathrm{C}(20)-\mathrm{C}(21)$ & $126.01(11)$ \\
$\mathrm{N}(4)-\mathrm{C}(20)-\mathrm{C}(21)$ & $119.37(11)$ \\
$\mathrm{C}(26)-\mathrm{C}(21)-\mathrm{C}(22)$ & $118.50(12)$ \\
$\mathrm{C}(26)-\mathrm{C}(21)-\mathrm{C}(20)$ & $120.98(11)$ \\
$\mathrm{C}(22)-\mathrm{C}(21)-\mathrm{C}(20)$ & $120.52(12)$ \\
$\mathrm{C}(23)-\mathrm{C}(22)-\mathrm{C}(21)$ & $120.96(13)$ \\
$\mathrm{C}(23)-\mathrm{C}(22)-\mathrm{H}(22)$ & 119.5 \\
$\mathrm{C}(21)-\mathrm{C}(22)-\mathrm{H}(22)$ & 119.5 \\
$\mathrm{C}(24)-\mathrm{C}(23)-\mathrm{C}(22)$ & $119.93(12)$ \\
$\mathrm{C}(24)-\mathrm{C}(23)-\mathrm{H}(23)$ & 120.0 \\
$\mathrm{C}(22)-\mathrm{C}(23)-\mathrm{H}(23)$ & 120.0 \\
$\mathrm{C}(23)-\mathrm{C}(24)-\mathrm{C}(25)$ & $119.82(13)$ \\
$\mathrm{C}(23)-\mathrm{C}(24)-\mathrm{H}(24)$ & 120.1 \\
$\mathrm{C}(25)-\mathrm{C}(24)-\mathrm{H}(24)$ & 120.1 \\
$\mathrm{C}(26)-\mathrm{C}(25)-\mathrm{C}(24)$ & $120.24(13)$ \\
$\mathrm{C}(26)-\mathrm{C}(25)-\mathrm{H}(25)$ & 119.9 \\
$\mathrm{C}(24)-\mathrm{C}(25)-\mathrm{H}(25)$ & 119.9 \\
$\mathrm{C}(25)-\mathrm{C}(26)-\mathrm{C}(21)$ & $120.54(12)$ \\
$\mathrm{C}(25)-\mathrm{C}(26)-\mathrm{H}(26)$ & 119.7 \\
$\mathrm{C}(21)-\mathrm{C}(26)-\mathrm{H}(26)$ & 119.7 \\
$\mathrm{C}(10)-\mathrm{N}(1)-\mathrm{N}(2)$ & $111.85(9)$ \\
$\mathrm{C}(10)-\mathrm{N}(1)-\mathrm{C}(1)$ & $129.65(10)$ \\
$\mathrm{N}(2)-\mathrm{N}(1)-\mathrm{C}(1)$ & $118.48(9)$ \\
$\mathrm{C}(7)-\mathrm{N}(2)-\mathrm{N}(1)$ & $107.02(9)$ \\
$\mathrm{C}(11)-\mathrm{N}(3)-\mathrm{C}(18)$ & $130.59(11)$ \\
$\mathrm{C}(11)-\mathrm{N}(3)-\mathrm{H}(3 \mathrm{~A})$ & $113.7(12)$ \\
$\mathrm{C}(18)-\mathrm{N}(3)-\mathrm{H}(3 \mathrm{~A})$ & $115.7(12)$ \\
$\mathrm{C}(18)-\mathrm{N}(4)-\mathrm{C}(20)$ & $110.24(11)$ \\
$\mathrm{C}(19)-\mathrm{S}(1)-\mathrm{C}(18)$ & $88.32(6)$ \\
& \\
\hline
\end{tabular}

Symmetry transformations used to generate equivalent atoms: 
Table S4 Anisotropic displacement parameters $\left(\AA^{2} \times 10^{3}\right)$

The anisotropic displacement factor exponent takes the form: $-2 \square^{2}\left[\mathrm{~h}^{2} \mathrm{a}^{* 2} \mathrm{U}^{11}+\ldots+2 \mathrm{~h} \mathrm{k} \mathrm{a}^{*} \mathrm{~b}^{*}\right.$ $\left.\mathrm{U}^{12}\right]$

\begin{tabular}{|c|c|c|c|c|c|c|}
\hline & $\mathrm{U}^{11}$ & $\mathrm{U}^{22}$ & $\mathrm{U}^{33}$ & $\mathrm{U}^{23}$ & $\mathrm{U}^{13}$ & $\mathrm{U}^{12}$ \\
\hline $\mathrm{C}(1)$ & $14(1)$ & $16(1)$ & $15(1)$ & $2(1)$ & $1(1)$ & $-2(1)$ \\
\hline$C(2)$ & $17(1)$ & $17(1)$ & 21(1) & 1(1) & $4(1)$ & 1(1) \\
\hline C(3) & $17(1)$ & $23(1)$ & $28(1)$ & $2(1)$ & $7(1)$ & $-2(1)$ \\
\hline C(4) & $22(1)$ & $19(1)$ & $31(1)$ & $2(1)$ & $5(1)$ & $-6(1)$ \\
\hline$C(5)$ & $24(1)$ & $16(1)$ & $29(1)$ & $-2(1)$ & $4(1)$ & $-1(1)$ \\
\hline$C(6)$ & $18(1)$ & $18(1)$ & $21(1)$ & $-1(1)$ & $4(1)$ & $0(1)$ \\
\hline$C(7)$ & $17(1)$ & $16(1)$ & $14(1)$ & $0(1)$ & $2(1)$ & 1(1) \\
\hline$C(8)$ & $18(1)$ & $15(1)$ & $24(1)$ & $-1(1)$ & $5(1)$ & $1(1)$ \\
\hline C(9) & $15(1)$ & $15(1)$ & $15(1)$ & $0(1)$ & $2(1)$ & $1(1)$ \\
\hline$C(10)$ & $14(1)$ & $18(1)$ & $13(1)$ & $1(1)$ & $2(1)$ & $-1(1)$ \\
\hline $\mathrm{C}(11)$ & $15(1)$ & $16(1)$ & $14(1)$ & $0(1)$ & $1(1)$ & $0(1)$ \\
\hline $\mathrm{C}(12)$ & $14(1)$ & $15(1)$ & $22(1)$ & $-2(1)$ & $5(1)$ & $-1(1)$ \\
\hline$C(13)$ & $21(1)$ & $20(1)$ & $22(1)$ & $-1(1)$ & $2(1)$ & $-3(1)$ \\
\hline$C(14)$ & $27(1)$ & $24(1)$ & $31(1)$ & $-8(1)$ & $2(1)$ & $-5(1)$ \\
\hline$C(15)$ & $37(1)$ & $16(1)$ & $42(1)$ & $-3(1)$ & $9(1)$ & $-5(1)$ \\
\hline$C(16)$ & $41(1)$ & $20(1)$ & $33(1)$ & $6(1)$ & $5(1)$ & $2(1)$ \\
\hline $\mathrm{C}(17)$ & $27(1)$ & $21(1)$ & $23(1)$ & 1(1) & 1(1) & 1(1) \\
\hline $\mathrm{C}(18)$ & $14(1)$ & $19(1)$ & $17(1)$ & $0(1)$ & $3(1)$ & $-2(1)$ \\
\hline C(19) & $15(1)$ & $24(1)$ & $28(1)$ & $2(1)$ & $7(1)$ & $-2(1)$ \\
\hline$C(20)$ & $13(1)$ & $22(1)$ & $16(1)$ & $0(1)$ & $2(1)$ & $-1(1)$ \\
\hline $\mathrm{C}(21)$ & $14(1)$ & $23(1)$ & $16(1)$ & $-1(1)$ & 1(1) & 1(1) \\
\hline $\mathrm{C}(22)$ & $17(1)$ & $24(1)$ & $28(1)$ & $-3(1)$ & $6(1)$ & $-2(1)$ \\
\hline $\mathrm{C}(23)$ & $16(1)$ & $32(1)$ & $33(1)$ & $-6(1)$ & $8(1)$ & $-1(1)$ \\
\hline $\mathrm{C}(24)$ & $20(1)$ & $30(1)$ & $34(1)$ & $-4(1)$ & $7(1)$ & $6(1)$ \\
\hline$C(25)$ & $27(1)$ & $23(1)$ & $37(1)$ & $3(1)$ & 11(1) & $3(1)$ \\
\hline$C(26)$ & $19(1)$ & $25(1)$ & $27(1)$ & $2(1)$ & $9(1)$ & $0(1)$ \\
\hline $\mathrm{N}(1)$ & $14(1)$ & $13(1)$ & $18(1)$ & $0(1)$ & $4(1)$ & 1(1) \\
\hline $\mathrm{N}(2)$ & $16(1)$ & $14(1)$ & $18(1)$ & $0(1)$ & $3(1)$ & $2(1)$ \\
\hline $\mathrm{N}(3)$ & $14(1)$ & $16(1)$ & $24(1)$ & $-1(1)$ & $5(1)$ & $-2(1)$ \\
\hline $\mathrm{N}(4)$ & $14(1)$ & $19(1)$ & $19(1)$ & $-1(1)$ & $3(1)$ & $-1(1)$ \\
\hline $\mathrm{O}(1)$ & $17(1)$ & $16(1)$ & $24(1)$ & $-1(1)$ & $6(1)$ & $2(1)$ \\
\hline$S(1)$ & $17(1)$ & $17(1)$ & $36(1)$ & $3(1)$ & $9(1)$ & $-1(1)$ \\
\hline
\end{tabular}


Table S5 Hydrogen coordinates ( x 10 $)$ and isotropic displacement parameters $\left(\AA^{2} \times 10^{3}\right)$

\begin{tabular}{lrrrl}
\hline & $\mathrm{x}$ & $\mathrm{y}$ & $\mathrm{z}$ & $\mathrm{U}(\mathrm{eq})$ \\
\hline & & & & \\
$\mathrm{H}(2)$ & -639 & 7115 & 3739 & 22 \\
$\mathrm{H}(3)$ & -1591 & 6246 & 4306 & 27 \\
$\mathrm{H}(4)$ & -1158 & 5236 & 3425 & 29 \\
$\mathrm{H}(5)$ & 241 & 5096 & 1954 & 28 \\
$\mathrm{H}(6)$ & 1202 & 5958 & 1345 & 23 \\
$\mathrm{H}(8 \mathrm{~A})$ & 996 & 9041 & 1023 & 28 \\
$\mathrm{H}(8 \mathrm{~B})$ & 1543 & 9053 & 3078 & 28 \\
$\mathrm{H}(8 \mathrm{C})$ & 414 & 8912 & 2783 & 28 \\
$\mathrm{H}(13)$ & 3829 & 8701 & 4048 & 25 \\
$\mathrm{H}(14)$ & 4235 & 9766 & 4380 & 33 \\
$\mathrm{H}(15)$ & 3875 & 10462 & 1912 & 38 \\
$\mathrm{H}(16)$ & 3090 & 10103 & -891 & 38 \\
$\mathrm{H}(17)$ & 2676 & 9037 & -1250 & 28 \\
$\mathrm{H}(19)$ & 6668 & 8293 & -868 & 26 \\
$\mathrm{H}(22)$ & 7694 & 7578 & -1664 & 28 \\
$\mathrm{H}(23)$ & 8849 & 6821 & -2144 & 32 \\
$\mathrm{H}(24)$ & 8555 & 5761 & -1544 & 33 \\
$\mathrm{H}(25)$ & 7106 & 5464 & -439 & 34 \\
$\mathrm{H}(26)$ & 5951 & 6221 & 57 & 28 \\
$\mathrm{H}(3 \mathrm{~A})$ & $3433(13)$ & $7276(9)$ & $780(20)$ & $35(5)$ \\
& & & & \\
\hline
\end{tabular}

Table S6 Torsion angles $\left[{ }^{\circ}\right]$

$$
\begin{aligned}
& \mathrm{C}(6)-\mathrm{C}(1)-\mathrm{C}(2)-\mathrm{C}(3) \\
& \mathrm{N}(1)-\mathrm{C}(1)-\mathrm{C}(2)-\mathrm{C}(3) \\
& \mathrm{C}(1)-\mathrm{C}(2)-\mathrm{C}(3)-\mathrm{C}(4) \\
& \mathrm{C}(2)-\mathrm{C}(3)-\mathrm{C}(4)-\mathrm{C}(5) \\
& \mathrm{C}(3)-\mathrm{C}(4)-\mathrm{C}(5)-\mathrm{C}(6) \\
& \mathrm{C}(4)-\mathrm{C}(5)-\mathrm{C}(6)-\mathrm{C}(1) \\
& \mathrm{C}(2)-\mathrm{C}(1)-\mathrm{C}(6)-\mathrm{C}(5) \\
& \mathrm{N}(1)-\mathrm{C}(1)-\mathrm{C}(6)-\mathrm{C}(5) \\
& \mathrm{N}(2)-\mathrm{C}(7)-\mathrm{C}(9)-\mathrm{C}(11) \\
& \mathrm{C}(8)-\mathrm{C}(7)-\mathrm{C}(9)-\mathrm{C}(11) \\
& \mathrm{N}(2)-\mathrm{C}(7)-\mathrm{C}(9)-\mathrm{C}(10) \\
& \mathrm{C}(8)-\mathrm{C}(7)-\mathrm{C}(9)-\mathrm{C}(10) \\
& \mathrm{C}(11)-\mathrm{C}(9)-\mathrm{C}(10)-\mathrm{O}(1)
\end{aligned}
$$

$$
\begin{gathered}
-0.13(18) \\
-179.42(11) \\
0.3(2) \\
-0.1(2) \\
-0.2(2) \\
0.3(2) \\
-0.15(18) \\
179.11(11) \\
-176.26(12) \\
6.2(2) \\
0.22(14) \\
-177.33(12) \\
-1.6(2)
\end{gathered}
$$


$\mathrm{C}(7)-\mathrm{C}(9)-\mathrm{C}(10)-\mathrm{O}(1)$

$\mathrm{C}(11)-\mathrm{C}(9)-\mathrm{C}(10)-\mathrm{N}(1)$

$\mathrm{C}(7)-\mathrm{C}(9)-\mathrm{C}(10)-\mathrm{N}(1)$

$\mathrm{C}(7)-\mathrm{C}(9)-\mathrm{C}(11)-\mathrm{N}(3)$

$\mathrm{C}(10)-\mathrm{C}(9)-\mathrm{C}(11)-\mathrm{N}(3)$

$\mathrm{C}(7)-\mathrm{C}(9)-\mathrm{C}(11)-\mathrm{C}(12)$

$\mathrm{C}(10)-\mathrm{C}(9)-\mathrm{C}(11)-\mathrm{C}(12)$

$\mathrm{N}(3)-\mathrm{C}(11)-\mathrm{C}(12)-\mathrm{C}(17)$

$\mathrm{C}(9)-\mathrm{C}(11)-\mathrm{C}(12)-\mathrm{C}(17)$

$\mathrm{N}(3)-\mathrm{C}(11)-\mathrm{C}(12)-\mathrm{C}(13)$

$\mathrm{C}(9)-\mathrm{C}(11)-\mathrm{C}(12)-\mathrm{C}(13)$

$\mathrm{C}(17)-\mathrm{C}(12)-\mathrm{C}(13)-\mathrm{C}(14)$

$\mathrm{C}(11)-\mathrm{C}(12)-\mathrm{C}(13)-\mathrm{C}(14)$

$\mathrm{C}(12)-\mathrm{C}(13)-\mathrm{C}(14)-\mathrm{C}(15)$

$\mathrm{C}(13)-\mathrm{C}(14)-\mathrm{C}(15)-\mathrm{C}(16)$

$\mathrm{C}(14)-\mathrm{C}(15)-\mathrm{C}(16)-\mathrm{C}(17)$

$\mathrm{C}(15)-\mathrm{C}(16)-\mathrm{C}(17)-\mathrm{C}(12)$

$\mathrm{C}(13)-\mathrm{C}(12)-\mathrm{C}(17)-\mathrm{C}(16)$

$\mathrm{C}(11)-\mathrm{C}(12)-\mathrm{C}(17)-\mathrm{C}(16)$

$\mathrm{S}(1)-\mathrm{C}(19)-\mathrm{C}(20)-\mathrm{N}(4)$

$\mathrm{S}(1)-\mathrm{C}(19)-\mathrm{C}(20)-\mathrm{C}(21)$

$\mathrm{C}(19)-\mathrm{C}(20)-\mathrm{C}(21)-\mathrm{C}(26)$

$\mathrm{N}(4)-\mathrm{C}(20)-\mathrm{C}(21)-\mathrm{C}(26)$

$\mathrm{C}(19)-\mathrm{C}(20)-\mathrm{C}(21)-\mathrm{C}(22)$

$\mathrm{N}(4)-\mathrm{C}(20)-\mathrm{C}(21)-\mathrm{C}(22)$

$\mathrm{C}(26)-\mathrm{C}(21)-\mathrm{C}(22)-\mathrm{C}(23)$

$\mathrm{C}(20)-\mathrm{C}(21)-\mathrm{C}(22)-\mathrm{C}(23)$

$\mathrm{C}(21)-\mathrm{C}(22)-\mathrm{C}(23)-\mathrm{C}(24)$

$\mathrm{C}(22)-\mathrm{C}(23)-\mathrm{C}(24)-\mathrm{C}(25)$

$\mathrm{C}(23)-\mathrm{C}(24)-\mathrm{C}(25)-\mathrm{C}(26)$

$\mathrm{C}(24)-\mathrm{C}(25)-\mathrm{C}(26)-\mathrm{C}(21)$

$\mathrm{C}(22)-\mathrm{C}(21)-\mathrm{C}(26)-\mathrm{C}(25)$

$\mathrm{C}(20)-\mathrm{C}(21)-\mathrm{C}(26)-\mathrm{C}(25)$

$\mathrm{O}(1)-\mathrm{C}(10)-\mathrm{N}(1)-\mathrm{N}(2)$

$\mathrm{C}(9)-\mathrm{C}(10)-\mathrm{N}(1)-\mathrm{N}(2)$

$\mathrm{O}(1)-\mathrm{C}(10)-\mathrm{N}(1)-\mathrm{C}(1)$

$\mathrm{C}(9)-\mathrm{C}(10)-\mathrm{N}(1)-\mathrm{C}(1)$

$\mathrm{C}(6)-\mathrm{C}(1)-\mathrm{N}(1)-\mathrm{C}(10)$

$\mathrm{C}(2)-\mathrm{C}(1)-\mathrm{N}(1)-\mathrm{C}(10)$

$\mathrm{C}(6)-\mathrm{C}(1)-\mathrm{N}(1)-\mathrm{N}(2)$

$\mathrm{C}(2)-\mathrm{C}(1)-\mathrm{N}(1)-\mathrm{N}(2)$

$\mathrm{C}(9)-\mathrm{C}(7)-\mathrm{N}(2)-\mathrm{N}(1)$

$\mathrm{C}(8)-\mathrm{C}(7)-\mathrm{N}(2)-\mathrm{N}(1)$

$\mathrm{C}(10)-\mathrm{N}(1)-\mathrm{N}(2)-\mathrm{C}(7)$

$\mathrm{C}(1)-\mathrm{N}(1)-\mathrm{N}(2)-\mathrm{C}(7)$

$\mathrm{C}(9)-\mathrm{C}(11)-\mathrm{N}(3)-\mathrm{C}(18)$

$$
\begin{gathered}
-178.44(12) \\
176.60(11) \\
-0.26(12) \\
179.17(12) \\
3.22(18) \\
2.8(2) \\
-173.12(11) \\
96.12(15) \\
-87.59(16) \\
-84.03(15) \\
92.26(15) \\
0.17(19) \\
-179.69(12) \\
-0.3(2) \\
0.3(2) \\
-0.3(2) \\
0.2(2) \\
-0.2(2) \\
179.69(12) \\
0.33(15) \\
-178.77(10) \\
172.83(13) \\
-6.23(18) \\
-7.7(2) \\
173.23(11) \\
-0.4(2) \\
-179.90(12) \\
0.4(2) \\
-0.2(2) \\
0.0(2) \\
-0.1(2) \\
0.3(2) \\
179.73(13) \\
178.44(11) \\
0.24(13) \\
0.0(2) \\
-178.21(11) \\
-11.39(19) \\
167.88(12) \\
170.25(11) \\
-10.48(16) \\
-0.07(13) \\
177.73(10) \\
-0.11(13) \\
178.53(10) \\
179.47(12) \\
\end{gathered}
$$


$\mathrm{C}(12)-\mathrm{C}(11)-\mathrm{N}(3)-\mathrm{C}(18)$

$\mathrm{N}(4)-\mathrm{C}(18)-\mathrm{N}(3)-\mathrm{C}(11)$

$\mathrm{S}(1)-\mathrm{C}(18)-\mathrm{N}(3)-\mathrm{C}(11)$

$\mathrm{N}(3)-\mathrm{C}(18)-\mathrm{N}(4)-\mathrm{C}(20)$

$\mathrm{S}(1)-\mathrm{C}(18)-\mathrm{N}(4)-\mathrm{C}(20)$

$\mathrm{C}(19)-\mathrm{C}(20)-\mathrm{N}(4)-\mathrm{C}(18)$

$\mathrm{C}(21)-\mathrm{C}(20)-\mathrm{N}(4)-\mathrm{C}(18)$

$\mathrm{C}(20)-\mathrm{C}(19)-\mathrm{S}(1)-\mathrm{C}(18)$

$\mathrm{N}(4)-\mathrm{C}(18)-\mathrm{S}(1)-\mathrm{C}(19)$

$\mathrm{N}(3)-\mathrm{C}(18)-\mathrm{S}(1)-\mathrm{C}(19)$
$-4.0(2)$

174.79(12)

$-6.4(2)$

$179.52(11)$

$0.57(14)$

$-0.57(15)$

$178.59(11)$

$-0.01(10)$

$-0.33(10)$

$-179.20(12)$

Symmetry transformations used to generate equivalent atoms:

Table S7 Hydrogen bonds [ $\left[\AA\right.$ and ${ }^{\circ}$.

\begin{tabular}{lccccc}
\hline $\begin{array}{l}\text { D-H...A } \\
\text { operator }\end{array}$ & $\mathrm{d}(\mathrm{D}-\mathrm{H})$ & $\mathrm{d}(\mathrm{H} \ldots \mathrm{A})$ & $\mathrm{d}(\mathrm{D} \ldots \mathrm{A})$ & $<(\mathrm{DHA})$ & Symmetry \\
$\mathrm{N}(3)-\mathrm{H}(3 \mathrm{~A}) \ldots \mathrm{O}(1)$ & $0.883(19)$ & $1.925(18)$ & $2.6901(13)$ & $144.1(17)$ & $\mathrm{x}, \mathrm{y}, \mathrm{z}$ \\
$\mathrm{C}(2)-\mathrm{H}(2) \ldots \mathrm{N}(2)$ & 0.95 & 2.43 & $2.7706(16)$ & 101 & $\mathrm{x}, \mathrm{y}, \mathrm{z}$ \\
$\mathrm{C}(6)-\mathrm{H}(6) \ldots \mathrm{O}(1)$ & 0.95 & 2.34 & $2.9626(15)$ & 122 & $\mathrm{x}, \mathrm{y}, \mathrm{z}$ \\
$\mathrm{C}(17)-\mathrm{H}(17) \ldots \mathrm{O}(1)$ & 0.95 & 2.42 & $3.2954(16)$ & 153 & $\mathrm{x}, 1 / 2-\mathrm{y}, \mathrm{1} / 2+\mathrm{z}$ \\
$\mathrm{C}(23)-\mathrm{H}(23) \ldots \mathrm{N}(2)$ & 0.95 & 2.61 & $3.5437(16)$ & 166 & $-1+\mathrm{x}, 1 / 2-\mathrm{y}, 1 / 2+\mathrm{z}$ \\
$\mathrm{C}(26)-\mathrm{H}(26) \ldots \mathrm{N}(4)$ & 0.95 & 2.55 & $2.8728(16)$ & 100 & $\mathrm{x}, \mathrm{y}, \mathrm{z}$ \\
& & & & & \\
\hline
\end{tabular}

